\title{
GEOARCHEOLOGICKÁ STUDIE VZNIKU, VYUŽÍVÁNÍ A ZÁNIKU HRADNÍHO PŘÍKOPU NA HRADĚ ROKŠTEJN
}

\author{
JANA MAZÁČKOVÁ - LENKA LISÁ
}

\begin{abstract}
Abstrakt: Vybudováni př́kopu (obj. 84) na hradě Rokštejně je spojováno s 1. stavebni fázi a propojeno s prvni písemnou zmínkou o hradě v roce 1289. Postupné zaplňování do skály vylámaného objektu sebou nese spoustu otázek ohledně formativních procesů vzniku uloženin a funkce vrstev jako ryze odpadnich, pochozich, vyrovnávacich apod. Velkou formativní zmènu vnesla do situace výstavba dolního paláce a hlavní hradby hradu po polovině 14. století a nakonec uzavření a dorovnání prostoru maltovou vyrovnávkou až za vlastnictví Rokštejna Valdštejny. Pro poznání formativnich procesủ byly záměrně odebrány z uloženin, které měly pochozi i odpadni charakter, vzorky pro mikromorfologický výzkum. Ten dopomohl interpretovat formováni uloženin výrazně sniženého prostoru a zpưsoby jeho zaplňování a využívání.
\end{abstract}

Klíčová slova: středověk - hrad-přikop - formativní procesy - archeologická stratigrafie-geoarcheologický výzkum - mikromorfologie - odpadový areál-komunikační schéma.

\section{A Geoarchaeological Study of the Origin, Usage and Decline of the Moat at Rokštejn Castle}

Abstract: The construction of the moat (feature 84) at Rokštejn Castle is associated with the first building phase and linked to the first written mention of the castle in 1289. The gradual filling of the feature carved in rock generated a large number of questions regarding the formation processes of the origin of the deposits and the function of the layers as purely waste ones, treading, levelling ones, etc. A major formation change was brought by the construction of the lower palace and the main wall of the castle after the mid-14 ${ }^{\text {th }}$ century, and finally by the closing and levelling of the space with a mortar fill in the period when Rokstejn was owned by the Valdštejns. In order to study the formation processes, samples for micromorphological research were deliberately taken from deposits that had both treading and waste character. The research helped interpret the formation of deposits in the distinctly sunken space and the manners of its filling and use.

Key words: Middle Ages - castle - moat - formation processes - archaeological stratigraphy - geoarchaeological research - micromorphology - waste area - communication diagram.

\section{1 Úvod}

Z dispozice hradních areálů a jejich archeologického obsahu lze usuzovat na části, které sloužily jako komunikační a odpadní areály. Formativní procesy v obou př́ípadech významně ovlivňuje člověk, a to udáním charakteru vrstvy (obsahu artefaktů nebo ekofaktů). Komunikační vrstva má stavebníkem požadovanou úpravu a po uvedení do provozu je nutné udržení její provozní stability, které se zabezpečuje úklidem a zpřístupněním komunikačních tras pro bezpečný chod sídla. Př́mé rozdělení na komunikační a odpadní areály v rámci hradní architektury lze dokumentovat především v době stabilizace sídla. Druhy produkovaného odpadu lze rozdělit mezi běžný provoz kuchyně, lidský odpad (prevéty), odpad výrobní (hradní kovárna), stavební nebo odpad hospodářský (chov zvířat). Velké a dramatické kumulace v hradním prostředí přestavují vrstvy stavebního odpadu, planýrek a kuchyňského odpadu. Rozloha a zastavěnost hradní parcely ovlivňuje deponování odpadu. Odpadové areály externího charakteru zaplňují mimokomunikační deprese, prostory v blízkosti staveb, nebo naopak doplňují komunikační prostor jako zpevňující prvek. Vzniklé většinou horizontální kulturní vrstvy jsou interpretovatelné jako možné pochozí horizonty, ale převládající formační proces nelze makroskopicky specifikovat (Durdík 2010, 47; Bajer a kol. 2013, 39-44; Schiffer 1972; 1983; 1987; Neustupný 2007, 66-72; Čapek 2013, 19-23, 64-72).

Jakým způsobem však interpretovat situaci, která vykazuje prvky komunikačního prostoru, ale z hlediska sedimentárního obsahu reflektuje odpadní areál? Jak lze jednotlivé fáze vyplňování rozpoznat a interpretovat? Jak v takovém případě pracovat se souborem artefaktů a sedimentárním archivem? Jednou z možností je detailní studium mikrostratigrafie doplněné o geochemickou analýzu (Goldberg-Macphail 2006; Lisá et al. 2015). 
Lokalita, na které lze studovat formační procesy interpretovatelné ve vztahu k jednotlivým fázím využívání hradního prostoru výše zmiňovaným metodickým přístupem, je např́íklad výplň hradního př́ikopu na hradě Rokštejně u Jihlavy. Výzkum této části hradu probíhal v letech 2009, 2010 a 2012. Studovaný objekt - tedy př́kop (obr. 1), byl označen číslem 84 . Tento prostor fungoval v poslední třetině 13. století a první polovině 14. století jako hradní príkop a je lokalizován mezi tzv. dolním palácem a horním hradem. Výplň příkopu ke skalnímu podloží dokumentovaná ve čtverci $6 / 8$ dosahuje $3 \mathrm{~m}$ a je tvořena makroskopicky odlišnými vrstvami (obr. 9) s horizontálním průběhem. Směrem do centra nádvoří hradu př́kop postupně vyznívá a stáčí se k severu. Jeho sklon se zvyšuje směrem k okraji skalního masivu, na kterém je hrad postaven. Příkop byl po polovině 14. století přehrazen západním úsekem hlavní hradby dolního hradu. Z archeologické situace je zřejmé, že zásadní změnu otevřeného prostoru představovala výstavba zděných objektů a následné překrytí maltovou vrstvou, což prostor uzavřelo pro vertikální stratigrafii a zvětšilo plochu nádvoří. Ve výsledku zde můžeme pozorovat sled uloženin odrážející rozdílné časové úseky formování výplně této antropogenně vzniklé deprese.

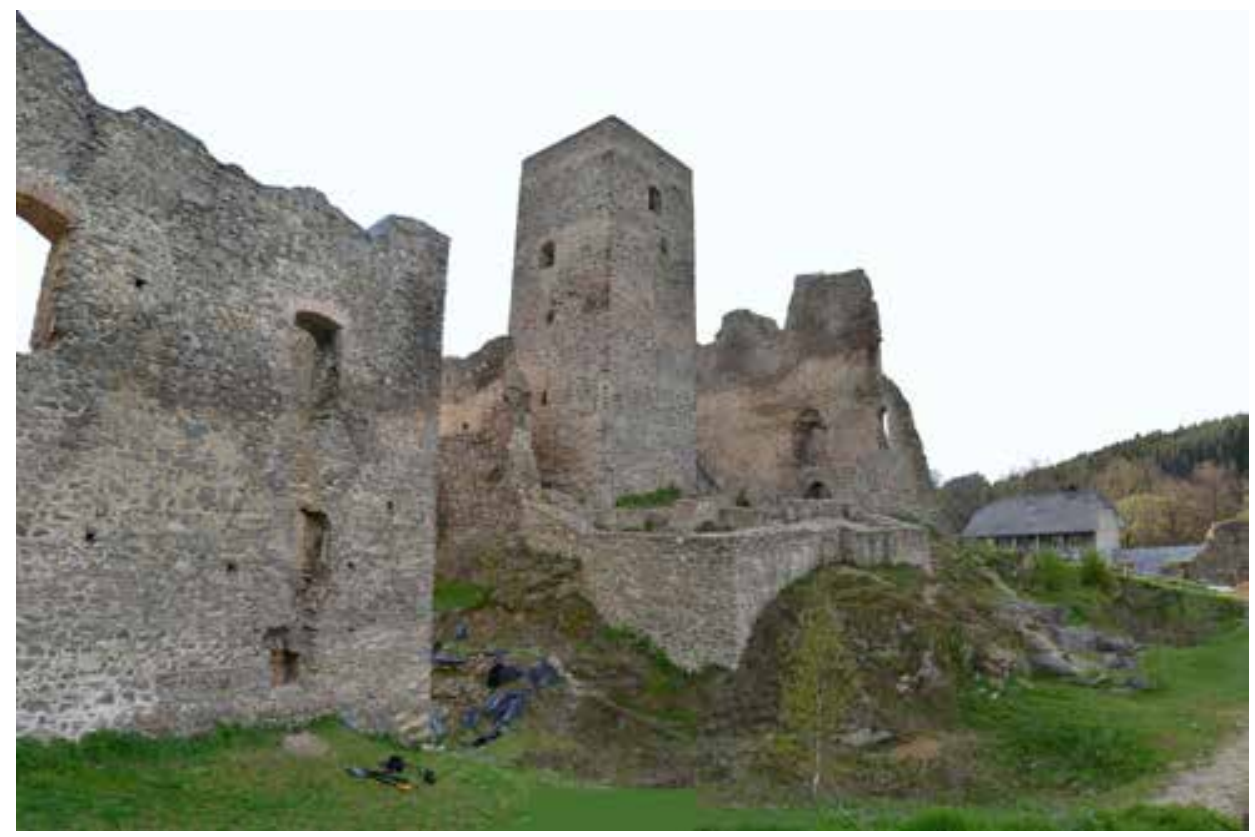

Obr. 1. Hrad Rokštejn. Pohled na horní hrad od jihovýchodu z prostoru dolního nádvoří. Pod nárožím hradby horního hradu je do skály vylámaný příkop (obj. 84) s viditelnými terénními vlnami a vyzníváním příkopu na východní straně (na obrázku vpravo). Foto J. Mazáčková.

Abb. 1. Burg Rokštejn. Blick auf die obere Burg von Südosten aus dem Raum des unteren Hofs. Unterhalb der Wehrmauerecke der oberen Burg befindet sich der im Felsen herausgebrochene Graben (Obj. 84) mit sichtbaren Geländewellen und dem an der Ostseite ausklingenden Graben (auf dem Bild rechts). Foto J. Mazáčková.

\subsection{Geologie a geomorfologie lokality}

Zř́́cenina hradu Rokštejn se nachází na k. ú. Panská Lhota (obr. 2:1). Jádro hradu stojí na skalním suku, který vybíhá ze severního svahu vrchu Pavlice $(551 \mathrm{~m}$ n. m.) v rozšířeném údolí na dolním toku řeky Brtnice, ca 1,5 km před jejím soutokem s řekou Jihlavou. Geologické podloží vlastní lokality je tvořeno melanokrátními granity až křemennými monzonity, tj. hlubinnými magmatity paleozoického stáŕí. Tyto horniny bývají také nazývány jako syenity Jihlavského masivu neboli durbachity. Jsou tvořeny především pyroxeny a biotity a svým zařazením patří do moravské větvě moldanubika. V bližším zařazení patří tato oblast do tzv. Jihlavského masivu (obr. 2:2). 
Ze současné morfologie terénu je zřejmé, že v minulosti byla plocha skalního výchozu výrazně modelována pro potřeby stavebníka. Stejně tak ji změnila i úprava prostoru horního i dolního nádvoří. Přímo pod hradem vede dnes náhon k objektu mlýna, který sloužil jako papírna již na počátku 19. století. V 16. století a patrně i v průběhu 15 . století v době existence hradu bylo údolí zalité vodou vodní nádrže s funkcí rybníka, v roce 1538 označovaného jako Velký rokštejnský. Rybník je vyobrazen ještě na mapách I. vojenského mapování. Po hrázi zaniklého rybníka jde v současné době komunikace od Přímělkova přes hradní areál směrem na Panskou Lhotu. Cesta prochází po bývalém východním parkánu hradu a vede jižním př́íkopem.

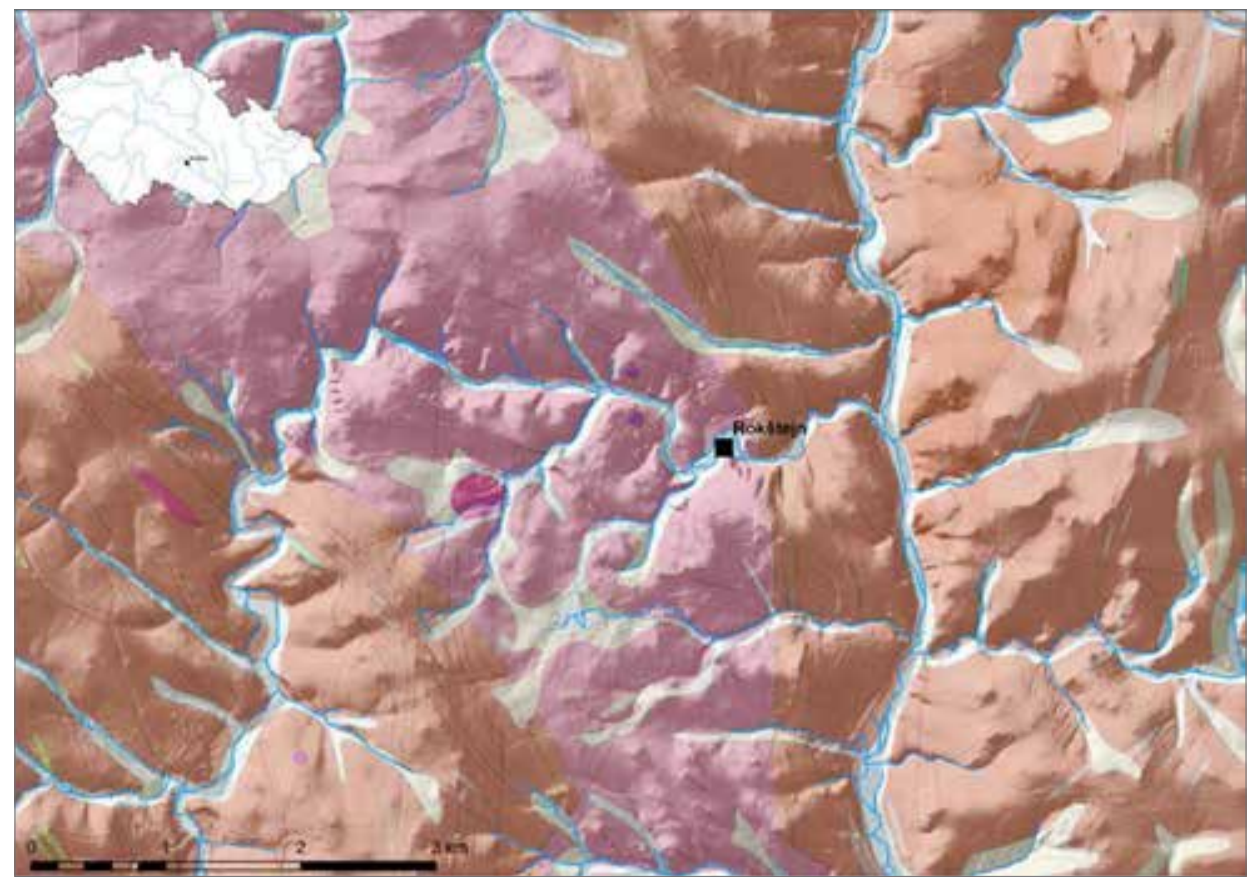

Obr. 2. Hrad Rokštejn v údolí řeky Brtnice severovýchodně od Panské Lhoty. Zjednodušená geologická mapa-pás hornin, na nichž je také lokalizován hrad, reprezentují melanokrátní granity až křemenné monzonity; okolní horniny jsou tvořeny především pararulami až migmatity s vložkami amfibolitů, pegmatitů a granitů. Zdroj wms služba; Geologická mapa 1 : 50000. Abb. 2. Burg Rokštejn im Tal des Flusses Brtnice nordöstlich von Panská Lhota. Vereinfachte geologische Karte - die Gesteinsstreifen, auf denen auch die Burg lokalisiert wird, werden durch melanokrate Granite und Quarz-Monzonite repräsentiert; die umliegenden Gesteine bilden vor allem Paragneise und Migmatite mit Einlagen von Amphiboliten, Pegmatiten und Graniten. Quelle Web Map Service; Geologische Karte 1 : 50000.

\subsection{Historie a stavební podoba hradu}

Rokštejn se poprvé uvádí v roce 1289 v souvislosti s rodem, který se píše z Ruthensteina. Na listině z roku 1289 vystupuje za třebíčským, želivským a zábrdovickým opatem „Ruthonis de Ruthenstein“. Po něm následují měšt’ané Jihlavy a listinu dále jako svědci potvrzují „Bernhardo de Ruthensteine et fratribus suius Zdislao et Wyrschone" (Bernhard z Ruthensteina a jeho bratři Zdislav a Vrš). Z uvedených bratrů se však jen Bernhard píše po hradě. Listina je vydána Theodorichem z Kněžic, který touto formou uděluje patronátní právo nad kostely v Opatově a v Moravanech knězi Jindřichovi a premonstrátům v Želivě. Rutho přivěsil k listině i svou pečet', která nese obraz leknínového listu beze stopky s neúplným opisem /VThC R///?nSTEIn (CDM VII, 776-777 č. 147; Sedláček 2003, 293, tab. 79:5). Opis obsahoval patrně formu jména a predikátu bez předložky Rutho Ruthonstein nebo s předložkou Ruth D. Ruthonstein. Jméno hradu odkazuje patrně na listinou uváděného Rutha, který mohl hrad založit, nebo na jakéhosi prapředka rodu 
stejného jména, a tím mohl být i jeden pánů z Kněžic nebo jejich potomek (Mazáčková 2013, 137-148; Vohryzek 2012, 1-8).

Kolem tohoto data stálo na nejvyšším místě skalního suku sídlo obehnané mohutnou $180 \mathrm{~cm}$ silnou na maltu zděnou kamennou hradbou. O jeho vnitřní zástavbě máme minimální informace, patrně šlo o obytnou stavbu se suterénem zahloubeným do skalního podloží v jihozápadní části opevněného prostoru nebo jinou neznámou zástavbu snesenou následnou nebo mladši přestavbou v severní části opevněného areálu zničeného definitivně výstavbou horního paláce.

Předhradí situované v prostoru dolního hradu uzavírala také mohutná hradba mocná až $2 \mathrm{~m}$. Horní hrad se vymezoval vůči předhradí ještě do skály vylámaným příkopem širokým až $7 \mathrm{~m}$, který zvýraznil oddělení horního hradu především proti severnímu svahu vrchu Pavlice. Námi zkoumaný př́kop (obj. 84) se stáčel pod jižní úsek hradu a vyzníval pod jeho východní částí. Vstup do horního hradu vedl přes př́íkop a byl vybudován na kủlové konstrukci.

Někdy kolem roku 1307 je dendrochronologicky (Šabatová-Soukup-Kyncl 2010, 207) datována přstavba hradu nastupující po prvním dokumentovaném zániku hradu, který se archeologicky projevil jako destrukce kamenných struktur (6-8-014) vyplňující hradní př́kop. Obdobná situace byla dokumentována $\mathrm{i} \mathrm{v}$ prostoru pozdějšího západního parkánu vytvářejícím $\mathrm{s}$ př́kopem $\mathrm{v}$ této době jeden organický prvek, kde se na vrstvu provozního charakteru uložily zbytky požáru a destrukce zdiva. Hrad se při obnově výrazně proměnil, na horním hradě byla postavena subtilní hranolová věž a nová obvodová hradba. Ta stála na substrukci zdiva staré destruované hradby. Její severní oblouk zničila výstavba horního paláce, který se ke snesené hradbě přistavěl. Změna na předhradí je prozatím dokumentována nejlépe charakterem výplně námi studovaného př́kopu (odpadní a pochozí vrstvy). Příkop přestal sloužit primárně defenzivnímu účelu minimálně ve své západní části, kde je doložen nárůst stratigrafie až o $80 \mathrm{~cm}$. Z nových hradních budov lze uvažovat o výstavbě východní věže a jakési kamenné stavby ve stávajícím severovýchodním nároží dolního hradu. $\mathrm{K}$ tomuto období máme velice málo písemných pramenů. S Rokštejnem lze spojit jistého moravského podkomořího Rutha zmíněného roku 1317, který by na základě svého postavení mohl iniciovat nákladnou přestavbu. K hradu totiž náleželo poměrně malé panství s několika vesnicemi. Ruthenštejni ztratili hrad poměrně záhy snad již někdy mezi lety 1339-1359 v souvislosti se změnou užívaného predikátu. Rokštejn byl v př́idomcích nahrazen Stř́žžovem (ZDB I/IV, 131 č. 541, 140 č. 712; CDM VI, 91 č. 116; CDM IX, 103 č. 127; Mazáčková 2013, 144-148; Vohryzek 2011, 46-50).

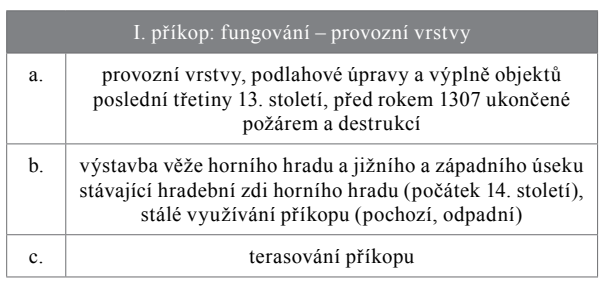

II. přestavba hradního areálu, rozšiření plochy: vzniklé planýrovací, stavební a provozní vrstvy druhé poloviny 14. až 15. století pod provozni vrstvou zánikového horizontu

\begin{tabular}{|c|c|}
\hline a. & $\begin{array}{l}\text { přestavba horního hradu - snesení části obvodového } \\
\text { zdiva hradby a její navýšení, výstavba horního paláce; } \\
\text { přestavba dolního hradu - výstavba dolního paláce, } \\
\text { výstavba obvodové hradby kolem dolního hradu }\end{array}$ \\
\hline b. & výstavba budovy C \\
\hline c. & $\begin{array}{l}\text { srovnání př́kopu (maltová vyrovnávka), výstavba } \\
\text { obj. 004/09 }\end{array}$ \\
\hline d. & výstavba hospodářských komor \\
\hline
\end{tabular}

\begin{tabular}{|c|c|}
\hline a. & provozní vrstva, bez stavebních aktivit \\
\hline b. & požárová vrstva \\
\hline
\end{tabular}

IV. destrukce hradu (sutové vrstvy) překrývající zánikový horizont

V. subrecentní zásahy v areálu hradu: výzkum hraběnky Collaltové, kuželkářská dráha, vznik komunikace v souvislosti s papirnou (převážně činnost 18.-19. století)

\begin{tabular}{|c|c|}
\hline & VI. recentní amatérský výzkum B. Coufala \\
\hline a. & archeologický výzkum \\
\hline b. & dostavba \\
\hline
\end{tabular}

VII. záchranný, pozdě̉i systematický archeologický výzkum

a. systematický archeologický výzkum od roku 1981 do současnosti (čtvercová sít' $5 \times 5 \mathrm{~m}$ )

b. restaurační a rekonstrukční práce Brtnice od roku 2004

Tab. 1. Archeologické horizonty doložené v areálu hradu Rokštejna.

Tab. 1. Im Areal von Burg Rokštejn belegte archäologische Horizonte. 
Další stavební změny přineslo až vlastnictví hradu markrabětem Janem Jindřichem a jeho syny. Markraběcí hrad se rozrostl o dva paláce (horní a dolní) a zformoval stávající hlavní hradební pás kolem dolního i horního hradu. Př́íkop byl v západní části přehrazen a na úpatí jižní strany př́ikopu (kontraeskarpy) byla postavena zed' dolního paláce. Hrad byl patrně rozšířen o severní předhradí, dnes zastavěné recentní zástavbou.

Na přelomu let 1398 a 1399 se podíl na panství a hradě dostává Valdštejnům a Tluksům. Valdštejni se stali jedinými držiteli panství někdy po roce 1414 a s nimi jsou spojeny poslední, nicméně velmi výrazné stavební aktivity $\mathrm{v}$ areálu hradu. Zarovnáním hradního př́ikopu a vytvořením komunikačního prostoru došlo $\mathrm{k}$ velké změně a rozšíření nádvoří. Vyrovnaný prostor byl posléze využit pro výstavbu různých kamenných objektů. Hrad fungoval patrně až do počátku 70. let 15 . století, kdy byl zničen vojenským zásahem (Mazáčková 2011, 61-85; 2013, 159; Vohryzek 2013, 84-85).

Dlouholetý systematický archeologický výzkum hradního areálu přináší možnosti podrobného studia formativních procesů a dovoluje sestavit základní nárys stratigrafického vývoje a jeho aplikaci do vývojových fází, které se nadále díky zpracovávání stále zpřesňují (tab. 1; Měŕínský 2007, 57-123; Mazáčková 2013, 192-200; 2013a, 255-289).

\subsection{Vývoj provozní plochy hradu}

Přírodní a antropogenní formační procesy vzájemně ovlivňují v určitém procentu zastoupení vznik archeologických pramenů - uloženin. Velký vliv na formační procesy se projevuje ve výběru skládek nebo odpadních míst a komunikačních ploch. Záměrné deponování odpadů z provozu hradu a vytvoření odpadového areálu ukazuje na speciální vydělování úseků s různou funkcí a zároveň na záměrné a specializované využívání prostoru. Hrad jako specifické architektonické sídlo s komunikačními zónami různého zatížení, které představují vztahy mezi existujícími strukturami (obytné, provozní objekty) v jedné fázi, a tak dovolují vytvořit model zatíženosti koridorů ve vtahu k úpravě jejich povrchů a formování a ovlivňování provozních nebo pochozích horizontů (nášlapových vrstev). Situace ovlivňuje př́stup k chápání zabezpečení vhodného komunikačního prostoru bez překážek se zpevněným nebo prašným povrchem pro rychlé a bezpečné spojení a venkovní provoz minimálně mezi dvěma objekty.

Při rekonstrukci vytíženosti komunikačních koridorů a jejich okolí jako nejvíce zatížených míst potřebných pro bezpečný a bezproblémový chod sídla je nutné je upravit proti možným rizikům provozu. Forma povrchů v exteriérech hradního sídla představuje několik různých podob. Detekce nezpevněných nebo zpevněných povrchů jsou základní rozlišovací možností. Nezpevněné komunikace $\mathrm{s}$ prašným povrchem stojí v kontrastu $\mathrm{s}$ uloženinami $\mathrm{s}$ výraznou kumulací odpadu a drobných kamenů jako zpevnění povrchu. Zpevněný povrch se projevuje jako různé formy kamenných dláždění, doplněné případným kuchyňským odpadem nebo stavebním odpadem využitým jako vyrovnávací a podkladová vrstva i pro komunikační účely.

Nejvytíženější jsou vstupní prostory do předhradí a vnitřního hradu, dále vstupy do obytných a provozních objektů nebo na fortifikační prvky (nástup na ochoz hradby). Na Rokštejně lze v různých časových horizontech doložit několik druhů úpravy komunikačních povrchů - maltová úprava (vápenná krusta), kamenné dláždění z drobných nepravidelných kamenů, popřípadě valounů, někdy doplněné běžným provozním odpadem tvořeným keramikou, kostmi a struskou. Patrně v interiérech se objevuje i kamenné dláždění z plochých kamenů (podlaha objektu 004/2009).

Každá stavební fáze měla svá komunikační specifika. Stavební fáze nebo archeologický horizont označený jako 1a představoval největší zatížení prostoru nádvoří horního hradu, ale prístup do něj lze rekonstruovat velice hypoteticky. Kamenná struktura v př́ikopu souvisí patrně s podezdívkou pro sloup dřevěného mostku až ve fázi 1 b. Předhradí zabíralo část nynějšího nádvoří dolního hradu, které bylo od vlastního jádra hradu odděleno do skály vylámaným příkopem. Vyplnění příkopu vypovídá o poměrně mocném nárůstu kulturních vrstev před zásadní přestavbou hradu datovanou k přelomu let 1306 a 1307. Jako komunikační se jevila vrstva 6-8-025 s mocností $20 \mathrm{~cm}$ a mírným sklonem jihozápadním směrem a vhodným povrchem pro komunikační využití (obr. 3). 

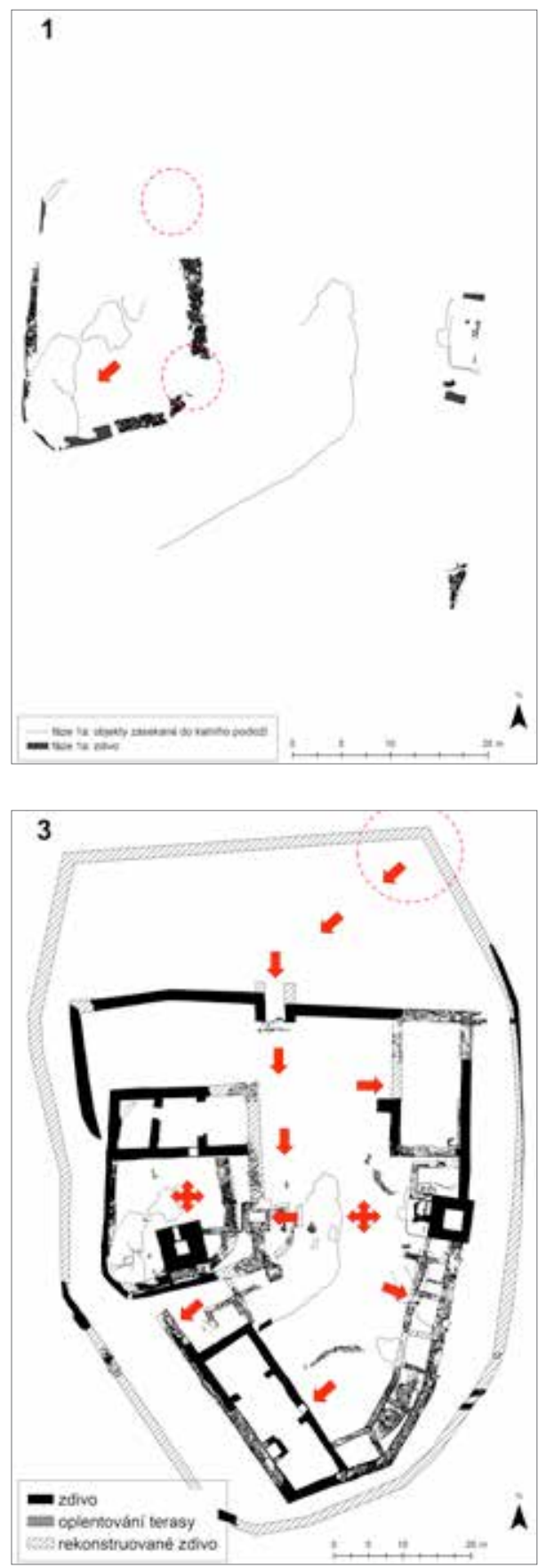

Obr. 3. Hrad Rokštejn. Rekonstrukce hlavních komunikačních tras v areálu hradu 1 - fáze Ia, 2 - fáze Ib, 3 - fáze III. Abb. 3. Burg Rokštejn. Rekonstruktion der Hauptverkehrswegetrassen im Burgareal 1 - Phase Ia, 2 - Phase Ib, 3 - Phase III.

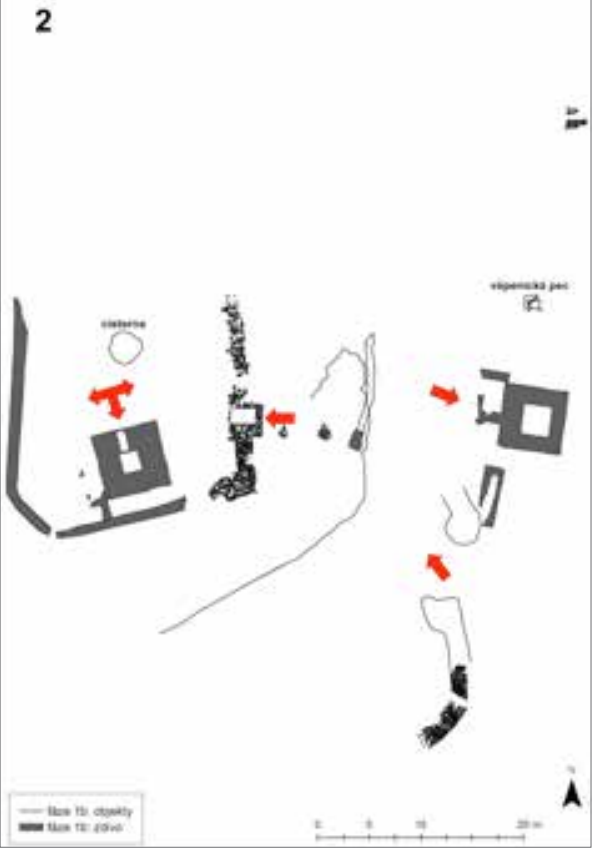

Cílem geoarcheologického výzkumu výplně hradního příkopu je získání relevantní informace o způsobu formování jednotlivých vrstev, jejich litologické náplni a způsobu využití prostory mezi několika časově odlišnými formativními a stavebními strukturami. Ty tvořily jádro samotného hradu a v určitém časovém úseku i součást préedhradí. Hospodářské funkce hradu se mohly odrazit právě $\mathrm{v}$ charakteru a formování uloženin. Antropogenní aktivity provázané s objektem hradního př́ikopu jsou spojovány $\mathrm{s} 1$. stavební fází a archeologickým horizontem 1a. Chronologicky se zároveň propojují s první písemnou zmínkou o hradu Rokštejně (Měřínský 2007, 62). Odběr vzorků proběhl v situacích vzniklých do poloviny 14 . století (viz níže).

2 Výsledky archeologického a geoarcheologického výzkumu

\subsection{Metodika archeologického výzkumu vý- plně př́kopu (obj. 84) ve čtverci $6 / 8$}

Čtverec $6 / 8$ byl při provádění archeologického výzkumu záměrně rozdělen na dvě části, západní a východní, tak aby severojižní profil A-B navazoval na profil kontrolního 
bloku v dolním paláci mezi čtverci C1-C2 a C3-C4 průhledem dveřního otvoru poškozeného v dolní části rozvalením (obr. 4). V letech 2005, 2006, 2012 byla zkoumána jeho východní část. V roce 2009 se přistoupilo i z bezpečnostních důvodů ke snížení východní části uloženin. Série vzorků pro mikromorfologickou analýzu byla odebrána v letech 2009 a 2012. Na základě výzkumu čtverce $7 / 8$ byla zjištěna situace formování objektu př́íkopu (obj. 84), zvlněné dno se sklání se západním směrem ke stávající západní hlavní hradbě, která zároveň představuje spolu se severní zdí dolního paláce základní formativní předěl uloženin. Exkavace probíhala po přirozených vrstvách.

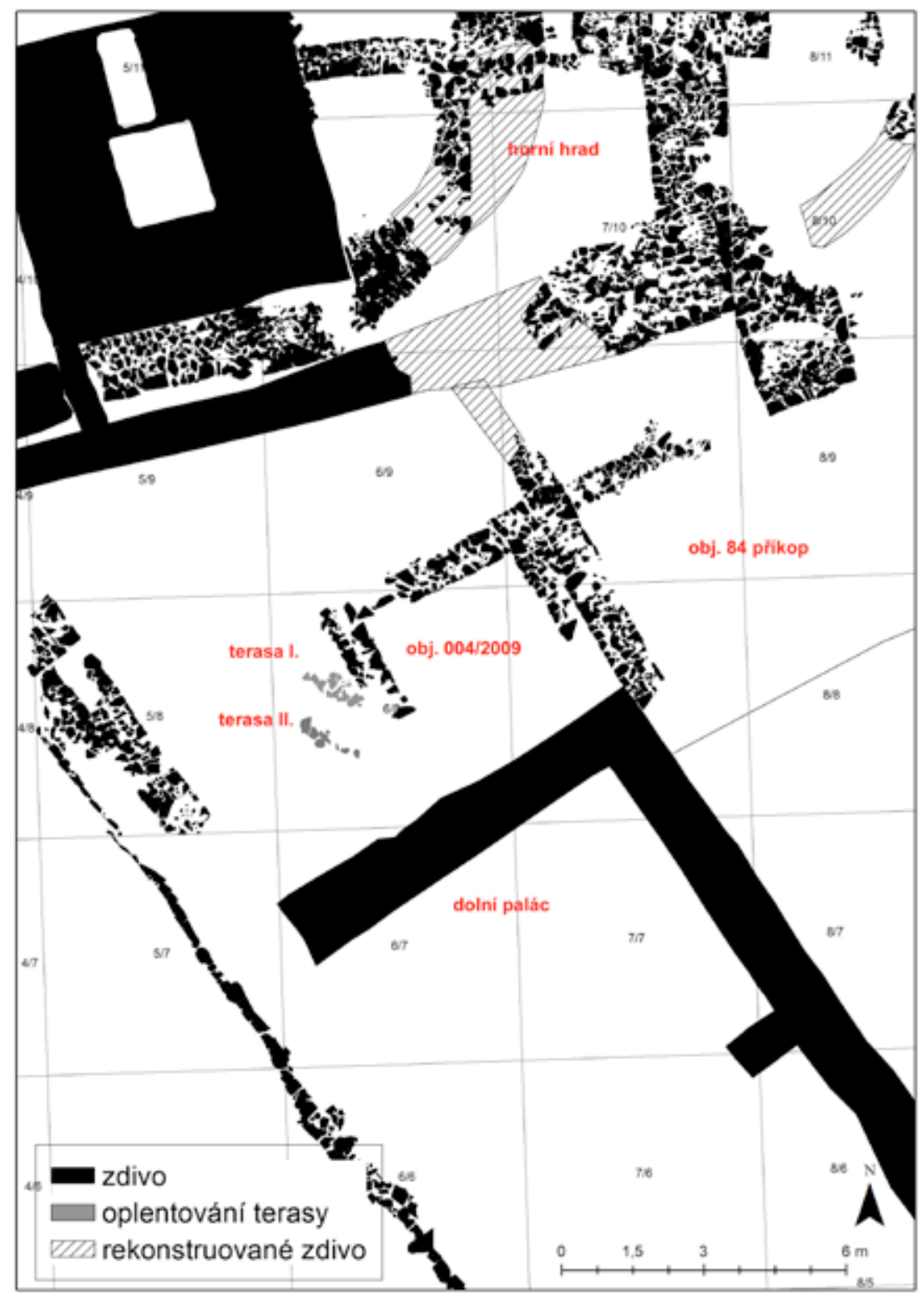

Obr. 4. Hrad Rokštejn. Zkoumaný čtverec 6/8.

Abb. 4. Burg Rokštejn. Untersuchtes Planum 6/8. 


\subsection{Výsledky archeologického výzkumu v př́kopu (obj. 84) ve čtverci 6/8}

Situace ve čtverci $6 / 8$ byla výrazně ovlivněna subrecentními a recentními antropogenními aktivitami, a to především ve 20 . a na počátku 21 . století (obr. $7 ; 8$ ). Jde o výkop amatérského archeologického výzkumu B. Coufala položený ke středu severní zdi dolního paláce s cílem detekovat hradní studnu. V popisu terénních prací uvádí, že k výkopům došlo 7.-8. července 1958 a že dosáhli dna s bezvýznamnými nálezy v podobě několika málo střepů (Coufal 1958, 2-3). Výkop narušil sled uloženin až na dno př́ikopu a vytvořil kráterovitou jámu, která na styku výrazně deformovala uloženiny 6-8-004, 6-8-025 a 6-8-003. Výplň této Coufalovy sondy tvořily v horní části především kameny (6-8-006-01) s promíseným zásypem z odtěžených vrstev (6-8-006-02). Při odkryvu došlo k degradaci zděné struktury (západní zed' objektu 004/2009, 6-8-003), a tak vznikl destrukční sesuv zdiva (6-8-003-01) po stěně vkopu. Coufalův výzkum zároveň narušil situace kameny oplentované terasy I. (6-8-037) a terasy II. (6-8-036). Vzniklá deprese, částečně zasypaná sonda Coufalova výzkumu pod severním vstupem do dolního paláce, byla posléze vyplněna zásypem promísených vytěžených uloženin z výzkumu roku 2001, který probíhal na západním parkáně. Další recentní zásyp představuje vrstva 6-8-001, která je také výsledkem přmístění prozkoumaných uloženin ze západního parkánu a je pozorovatelná na západním profilu mezi čtverci 6/8 a 5/8. Výplň (6-8-045) trychtýřovitého vkopu převážně kamenitého rázu na stejném profilu představuje neznámý zásah, starší než výzkum B. Coufala; tento vkop je v superpozici s ještě jedním starším zásahem vyplněným zásypem (6-8-044), který má charakter převážně organogenní vrstvy černé barvy.

Středověkou strukturu představuje destrukce a zánik na kámen zděného objektu (004/2009). Několikafázový objekt byl postaven po roce 1400, a to s využitím starší terasy I. (6-8-037). Objekt zničil požár při zániku hradu. Všechny tři zjištěné zdi stavby narušily základovým vkopem maltovou vrstvu (6-8-027), v jehož výplni se v severozápadním rohu projevila vrstva 6-8-039, která byla silně promísená $\mathrm{s}$ uhlíky. Uloženina byla zbytkem po původním pyrotechnologickém zařízení, s následnou tradicí v tomto místě, která významně ovlivnila formování dalších situací (Mazáčková-Měřínský 2011, 18). Provozní vrstvu objektu tvořila nášlapová vrstva vzniklá na dlažbě uložené v písčité vrstvě s výrazným podílem vápenné malty (6-8-022). V této vyrovnávce se rýsovaly výplně sloupových jam. Ty procházely maltovou podlahou (6-8-027), která se primárně kolem nich zformovala. Sloupy vytvářely půloblouk u zdi dolního paláce, jejich další průběh západním směrem narušil Coufalův výzkum. Destrukce zděných struktur (6-8-002) překrývaly západní zed' (6-8-003) objektu 004/2009. Zídka se dochovala ve čtyřech až šesti zděných šárech na maltu a byla založena na uloženině 6-8-004 a v severozápadním rohu na uloženině 6-8-039. Vrstva 6-8-004 vytvářela dorovnání prostoru, na kterém se dále formovaly aktivity spojené až s Valdštejny. Toto tvrzení je založeno na nálezu kování nákončí opasku s rodovým znakem Valdštejnů, jde o lvici ve výskoku (obr. 5) z vrstvy 7-8-011, ze čtverce $7 / 8$, která odpovídá stratigrafické jednotce 6-8-004.

Západní profil čtverce $6 / 8$ dokumentuje situace vrstev 6-8-042, 6-8-041, 6-8-040, 6-8-017, 6-8-044 a 6-8-045, které neprobíhají odkrytým prostorem, uloženiny byly narušeny Coufalovým výzkumem a nebyly prozatím zkoumány, zůstalo jen u dokumentace v zešikmeném profilu kopírujícím Coufalův výkop. Uloženiny 6-8-041 a 6-8-017 představují maltové vyrovnávky, z nichž 6-8-017 vi-

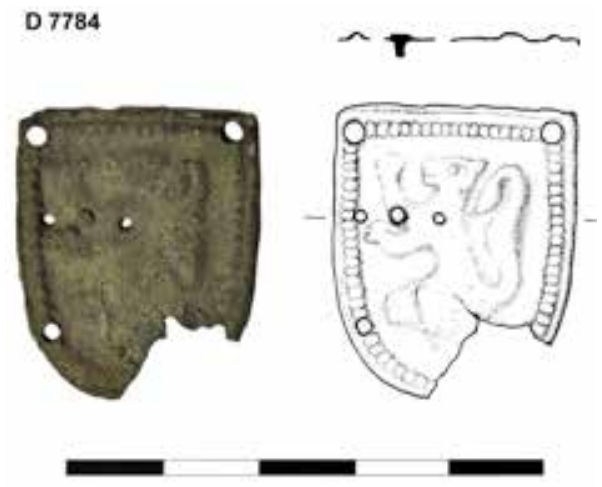

Obr. 5. Hrad Rokštejn. Nákončí opasku s rodovým znakem Valdštejnů. Foto J. Mazáčková, kresba S. Plchová. Abb. 5. Burg Rokštejn. Riemenzungen mit Familienwappen der Waldsteins. Foto J. Mazáčková, Zeichnung S. Plchová. 
ditelně přiléhá $\mathrm{k}$ severní zdi dolního paláce, a tak dorovnala a vhodně upravila původně svažitý prostor dosypaný vrstvou 6-8-035. Maltová vyrovnávka 6-8-017 výškově koresponduje s dochovanou maltovou úpravou ve východní části čtverce 6/8 (6-8-027) a ve čtverci 7/8 jako uloženina 7-8-003. Uloženina 6-8-035 dorovnává prostor a přiléhá k terase I. (6-8-037), ale její průběh není kontinuální, narušují jej subrecentní a recentní zásahy (6-8-044 a 6-8-045).

Uzavření situace $\mathrm{v}$ bývalém př́íkopu představovaly vyrovnávací vrstva 6-8-035 a maltové úpravy 6-8-027 a 6-8-017, na které se zformovala vrstva 6-8-040, opět překrytá maltovou vyrovnávkou. Vrstva 6-8-040 vykazuje shodné prvky s uloženinou vzniklou na maltové úpravě objektu 004/2009, ale narušení Coufalovým vkopem výrazně ovlivnilo čitelnost situace.

Uloženiny 6-8-035 a 6-8-004 jsou posledními, které přiléhají k severní zdi dolního paláce a překrývají výplň základového vkopu pro jeho zed' (6-8-021). Severní zed' dolního paláce je $\mathrm{v}$ jeho severovýchodním nároží založena na maltou vylitém kamenném základě založeném přímo do uloženin dvou posledních vrstev čtverce $7 / 8$. Situace v Coufalově výkopu ve čtverci $6 / 8$ a zároveň na profilu $6 / 8$ s 5/8 zachycují úzký základový vkop s jednolitou výplní a výstavbou nerovného líce severní zdi paláce. Vkop následně přechází v prosté vyplnění stavební jámy vylitím základu. Tato metoda výstavby zdiva je stupňovitě aplikována ve shodě se svažitostí terénu. V horní části má stavební vkop šiřku až $60 \mathrm{~cm}$ a poměrně rychle se zužuje.

Před výstavbou dolního paláce bylo použito na severním svahu příkopu terasování s kamenným oplentováním. Terasy jsou doloženy v př́ikopu dvě, z nichž terasa I. je stratigraficky mladší. Terasa I. je založena na vrstvách zaniklé terasy II. a vznikla současně s vyrovnávkou 6-8-004. Terasa II. je dochovaná jen v torzu a narušená částečně nejstarším recentním zásahem. Základ tělesa terasy byl vytvořen odtěžením původních uloženin 6-8-009 a částečně i 6-8-012. Těžba se na 6-8-012 zastavila z důvodu výrazného procentuálního zastoupení kamenů ve vrstvě. Z kamenů bylo vybudováno na sucho skládané oplentování (6-8-036) na fragmentech původních uloženin a vysypáno. Oplentování ze třech řad kamenů je založeno na kumulaci kamenů ve vrstvě 6-8-012. Provozní vrstva terasy byla s určitostí 6-8-010, na které vznikla 6-8-015 a představovala poslední provozní vrstvu fungující s oplentováním terasy I. Lze ji definovat jako odpadní lehkou neulehlou uloženinu s výrazným zastoupením uhlíků. Vzniklá snížená plocha u paty plenty dovolila zformovat vrstvu 6-8-018 současnou se 6-8-010, popřípadě i s vrstvou 6-8-015 nebo s následnou 6-8-008, které jsou narušeny antropogenním zásahem a částečně odtěženy. $\mathrm{V}$ př́ikopu fungovala terasa se zhutněnou komunikační úpravou, kterou překryla jeho destrukční a odpadová vrstva 6-8-015.

Uloženiny 6-8-020 (silně ulehlá) a 6-8-019 vznikaly jako vyrovnávky a odpadní vrstvy prostoru, který se skláněl v severojižním směru. Prostor byl srovnán a navýšen o $50 \mathrm{~cm}$ a následně narušen výkopem pro základ zdi dolního paláce.

Formování výplně př́íkopu před výstavbou teras jako dalších výrazných formativních předělů poukazovalo na dorovnání zešikmení vzniklého ukládáním uloženin v př́ikopu. Sled uloženin pod 6-8-009 (provozní $20 \mathrm{~cm}$ mocná šedá vrstva s odpadem, interpretována i jako pochozí; v dolní části vrstvy se koncentrovaly drobné i větší kameny o velikosti $5-15 \mathrm{~cm}$ ), dále následovala stavební vyrovnávka 6-8-012 s proplástkou vrstvy 6-8-011, pod nimi uloženina 6-8013 obdobného charakteru k vrstvě 6-8-009. Vrstva 6-8-013 vytváří výplň mezi velkými kameny, které byly součástí destrukční vrstvy 6-8-014. Uloženina 6-8-014 představovala destrukční vrstvu zděné struktury spadlé patrně z horního hradu do př́ikopu a následně vyplněné vrstvou 6-8-013 jako provozní vrstvou (odpadní i možná pochozí funkce). Uloženina 6-8-014 překrývala vrstvu 6-8-025, která vytvářela opět další provozní (odpadový i pochozí) horizont v př́íkopu. Tato vrstva se zformovala na vrstvě 6-8-033, která tvoří patrně již jednolitou výplň až ke dnu prríkopu. Toto zjištění bylo provedeno na základě vybrání zásypu ze vkopu Coufalova výzkumu. Výzkum se v západní části čtverce zatím zastavil na povrchu 6-8-025. Destrukce 6-8-014 spadlá na 6-8-025 překryla na kontaktu obou vrstev i nález militarií, a to dva hroty šípů (obr. 6).

Základní časové vymezení vzniku maltové vyrovnávky se posunulo minimálně o půl století výše s nálezem artefaktu nákončí opasku s valdštejnskou lvicí. Na základě této skutečnosti byla zařazena maltová vyrovnávka (6-8-027) příkopu až do valdštejnského období vývoje hradu, 


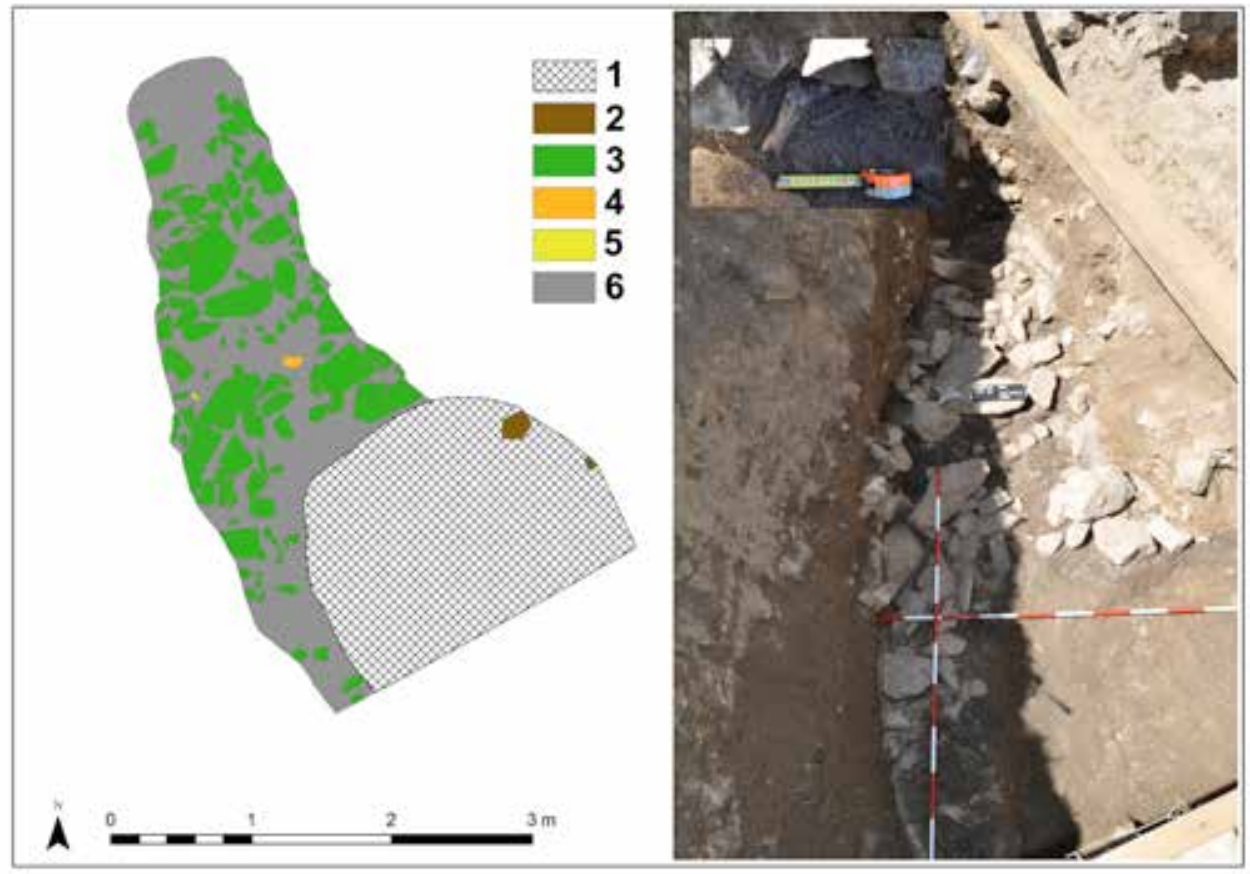

Obr. 6. Hrad Rokštejn. Zkoumaný čtverec 6/8. 1 - v. 006-01 (vkop B. Coufala); 2 - v. 006-01 - kámen; 3 - v. 014 - kámen (destrukce horního hradu z počátku 14. století); 4 - v. 025 - keramika; 5 - v. 025 - kost, v. 025 - provozní horizont, který se jevil jako komunikační prostor. Foto - identická situace ve čtverci 6/8, destrukce vrstvy 6-8-014 spadlá na provozní horizont vrstvy 6-8-025, které jsou narušené vkopem B. Coufala, v detailu hrot šípu s trnem související s destrukcí hradu. Foto J. Mazáčková.

Abb. 6. Burg Rokštejn. Untersuchtes Planum 6/8. 1 - Schicht 006-01 (Aushebung B. Coufala); 2 - Schicht 006-01 - Stein; 3 Schicht 014 - Stein (Zerstörungsschicht der oberen Burg vom Anfang des 14. Jhdts.); 4 - Schicht 025 - Keramik; 5 - Schicht 025 - Knochen, Schicht 025 - Betriebshorizont, der sich als Verkehrsweg erwies. Foto - identische Situation in Planum 6/8, die Zerstörungsschicht 6-8-014 fiel in den provisorischen Horizont von Schicht 6-8-025, welche durch die von B. Coufal angelegte Aushebung gestört ist, Detail einer mit der Zerstörungsschicht der Burg zusammenhängende Pfeilspitze mit Dorn. Foto J. Mazáčková.

stejně jako sama přestavba doprovázená vrstvou 6-8-004 a vznikem terasy I. Sekvence vrstev i teras představuje vývoj od poslední třetiny 13. století do konce první poloviny 14 . století. Výstavba paláců je nadále spojována s markrabětem.

Lze tedy konstatovat, že vrstva 6-8-025 představuje patrně jeden z prvních horizontů př́íkopu vyplněný výrazně odpadním materiálem. Vrstvu také charakterizoval zarovnaný povrch místy doplněný valouny (velikost $5-15 \mathrm{~cm}$ ). Tuto vrstvu překryla destrukce hradu, kterou lze spojit s událostmi někdy před rokem 1306/1307, a to na základě dendrochronologického výzkumu dřevěných prvků dochovaných v hranolové věži horního hradu (Šabatová-Soukup-Kyncl 2010, 207).

\subsection{Výsledky geoarcheologického výzkumu}

\subsubsection{Použitá metodika geoarcheologického výzkumu}

Po začištění a dokumentaci profilu byly odebrány celkem čtyři mikromorfologické vzorky o rozměrech $6 \times 9 \mathrm{~cm}$ a pět geochemických vzorků pro potřeby multiprvkové analýzy. Mikromorfologické vzorky byly odebrány z vrstev 6-8-015, 6-8-010 a 6-8-009, uprostřed vrstvy 6-8-009, 6-8-013 a vrstvy 6-8-025 (obr. 8:1-2). Vzorky byly vysušeny, naimpregnovány ve vakuu pryskyřicí a poté nařezány a následně vybroušeny do podoby pedologických výbrusů. Mikromorfologická charakteristika byla provedena podle Bullocka a Murphyho (1983), Stoopse (2003) a Kempa (2007). Geochemické vzorky byly pomocí metody ICP (Inductively coupled plasma) 

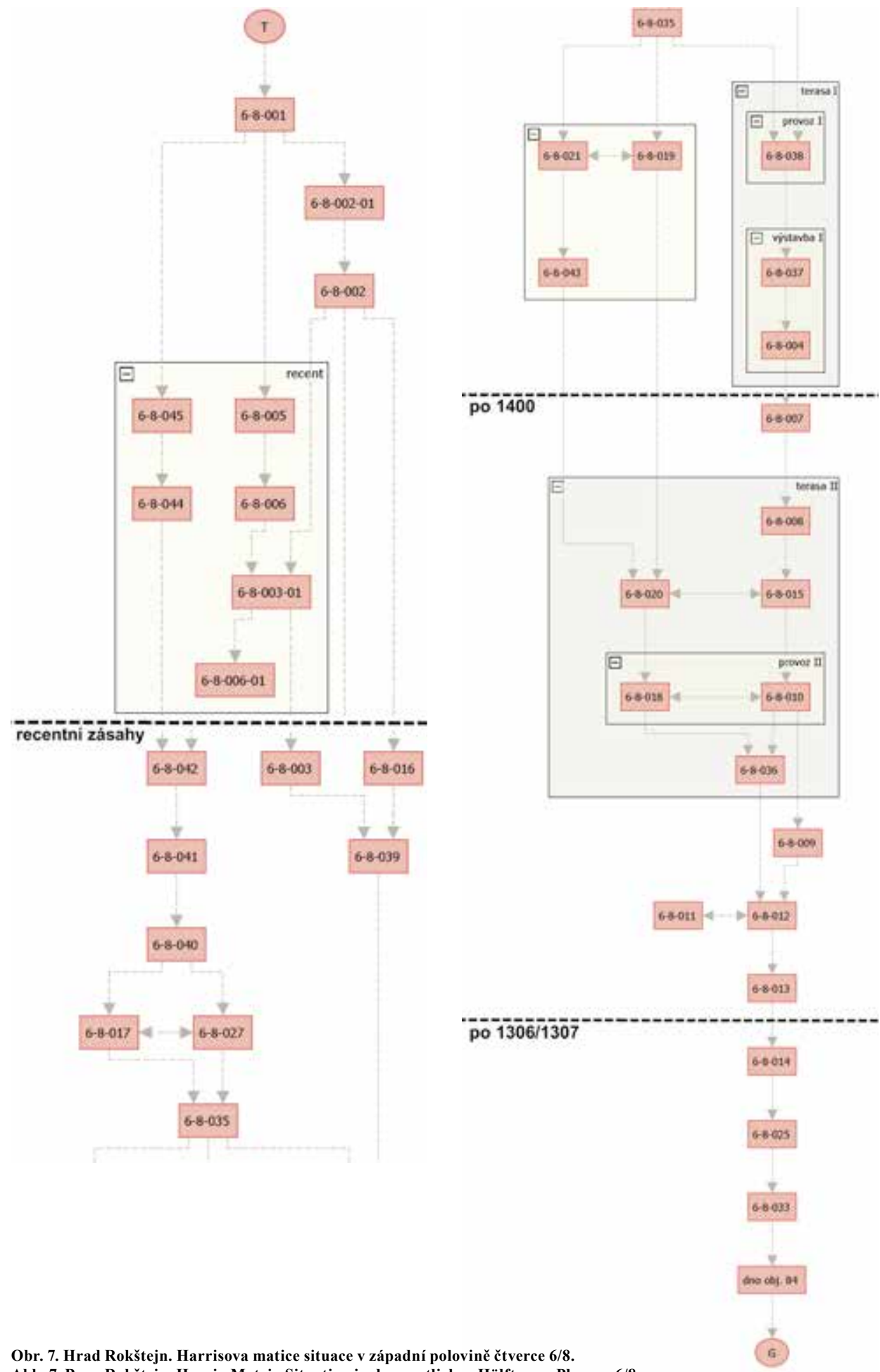

Obr. 7. Hrad Rokštejn. Harrisova matice situace v západní polovině čtverce 6/8.
Abb. 7. Burg Rokštejn. Harris-Matrix Situation in der westlichen Hälfte von Planum 6/8. 
vyhodnoceny, přičemž byly stanoveny obsahy $\mathrm{Al}, \mathrm{Ca}, \mathrm{Fe}, \mathrm{K}, \mathrm{Mg}, \mathrm{Mn}, \mathrm{Na}, \mathrm{P}$ a S v laboratoři environmentální geochemie Geologického ústavu AV ČR, v. v. i., v Praze. Magnetická susceptibilita byla měřena na př́stroji kapabridge v Geologickém ústavu AV ČR, v. v. i., v Praze.
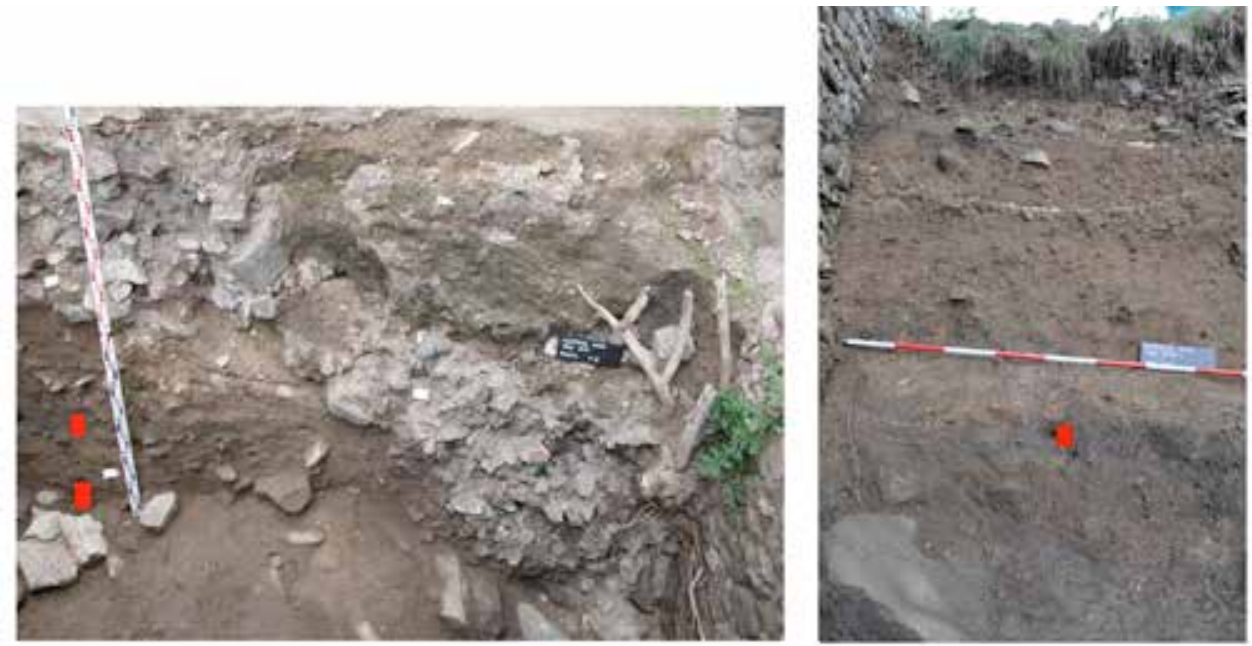

Obr. 8. Hrad Rokštejn. Foto vlevo - čtverec 6/8, profil A-B s vyznačením odběru vzorků M2 (horní) a M5 (dolní); foto vpravo - čtverec 6/8 profil se čtvercem 5/8 (západní profil) s vyznačením odběru vzorku M4. Foto J. Mazáčková.

Abb. 8. Burg Rokštejn. Foto links - Planum 6/8, Profil A-B mit eingezeichneten Entnahmestellen der Proben M2 (oben) undM5 (unten); Foto rechts - Planum 6/8 Profil mit Planum 5/8 (Westprofil) mit einegzeichneter Entnahmestelle von Probe M4. Foto J. Mazáčková.

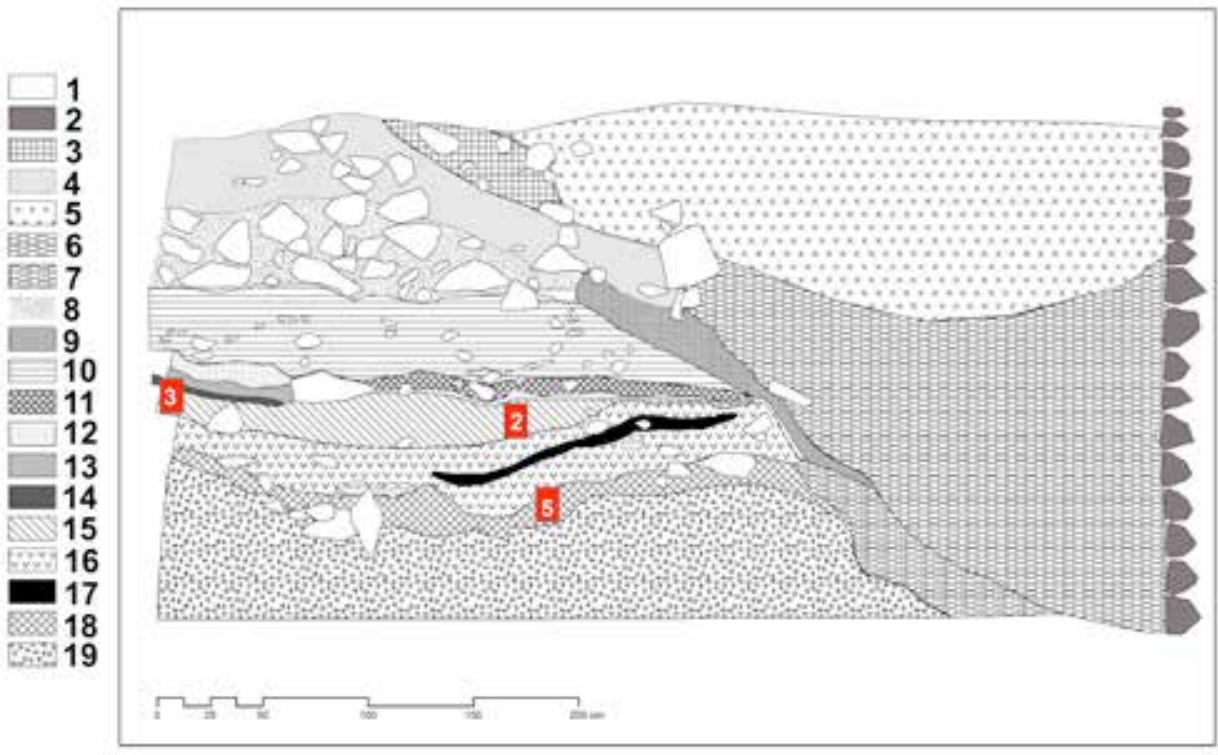

Obr. 9. Hrad Rokštejn. Zkoumaný čtverec 6/8. Profil A-B s vyznačením míst odběrů vzorků M2 (2), M3 (3), M5 (5). 1 kámen; 2 - zdivo; 3 - 6-8-002-01; 4 - 6-8-002; 5 - 6-8-005; 6 - 6-8-006; 7 - 6-8-006-01; 8 - 6-8-003; 9 - 6-8-003-01; 10 - 6-8-004; 11 - 6-8-007; 12 - 6-8-008; 13 - 6-8-015; 14 - 6-8-010; 15 - 6-8-009; 16 - 6-8-012; 17 - 6-8-011; 18 - 6-8-013; $19-6-8-014$.

Abb. 9. Burg Rokštejn. Untersuchtes Planum 6/8. Profil A-B mit eingezeichneten Entnahmestellen der Proben M2 (2), M3 (3), M5 (5). 1 - Stein; 2 - Mauerwerk; 3 - 6-8-002-01; 4 - 6-8-002; 5 - 6-8-005; 6 - 6-8-006; 7 - 6-8-006-01; 8- 6-8-003; 9-6-8-003-01; 10 - 6-8-004; 11 - 6-8-007; 12 - 6-8-008; 13 - 6-8-015; $14-6-8-010 ; 15-6-8-009 ; 16-6-8-012 ; 17-6-8-011$; $18-6-8-013 ; 19-6-8-014$. 


\subsubsection{Sedimentologický popis}

Jednotlivé horizonty jsou v úseku profilu A-B čtverce 6/8 odlišeny na základě rozdílné litologie. Úsek profilu A-B byl při odběru vzorků M2 a M5 dokumentován (obr. 10). V tomto profilu však při prvním odběru nebyla zachycena vrstva (proplástek) 6-8-010 (obr. 9), ze které byl odebírán v následující sezóně mikromorfologický vzorek M3 a uloženina 6-8-025, ze které byl odebrán v následující sezóně mikromorfologický vzorek M4 (obr. 8:2).

Horizont 1 zahrnuje archeologicky vyčleněné vrstvy 6-8-004, 6-8-007, 6-8-008 (obr. 9), metráž od povrchu je $80-120 \mathrm{~cm}$. Horizont je makroskopicky charakterizován jako sypký nevytř́íděný detritický materiál. Zrnitost matrix prachovitopísčitá, velikost jednotlivých klastů do ca $10 \mathrm{~cm}$. Zastoupení detritu ca do $20 \%$. Barva průměrně kolísá mezi 10YR 6/2-5/2 (světle hnědá až hnědošedá), vápnitá. Přechod do podloží je ostrý. V nadloží stěna mladšího objektu.

Horizont 2 zahrnuje archeologicky vyčleněné vrstvy 6-8-015, 6-8-010, 6-8-009 (obr. 10), metráž od povrchu je 120-145 cm. Horizont je makroskopicky charakterizován jako stř̌edně vytrríděný, prachovitojílovitý sediment s obsahem detritu o velikosti jednotlivých ostrohranných až polozaoblených klastů ca 0,5-1 cm. Barva je dle Munsela 7,5YR 6/3-6/4 (světle hnědá). Zastoupení detritu ca do $20 \%$. Obsahuje fragmenty keramiky (5\%), uhlíků (10 \%) a kostí (do $1 \%$ ). Přechod do podloží je ostrý (obr. 10). V severním úseku čtverce $6 / 8$ byla na povrchu této vrstvy identifikována jílovitá zhutnělá vrstvička o mocnosti ca $2 \mathrm{~cm}$. Její barva byla určena jako světle hnědošedá (10YR 6/2). Na jejím povrchu byly místy identifikovány uhlíky do velikosti ca $1 \mathrm{~cm}$. V jejím nadloží byla další několik centimetrů mocná vrstva analogická vrstvě 6-8-015 (obr. 9).

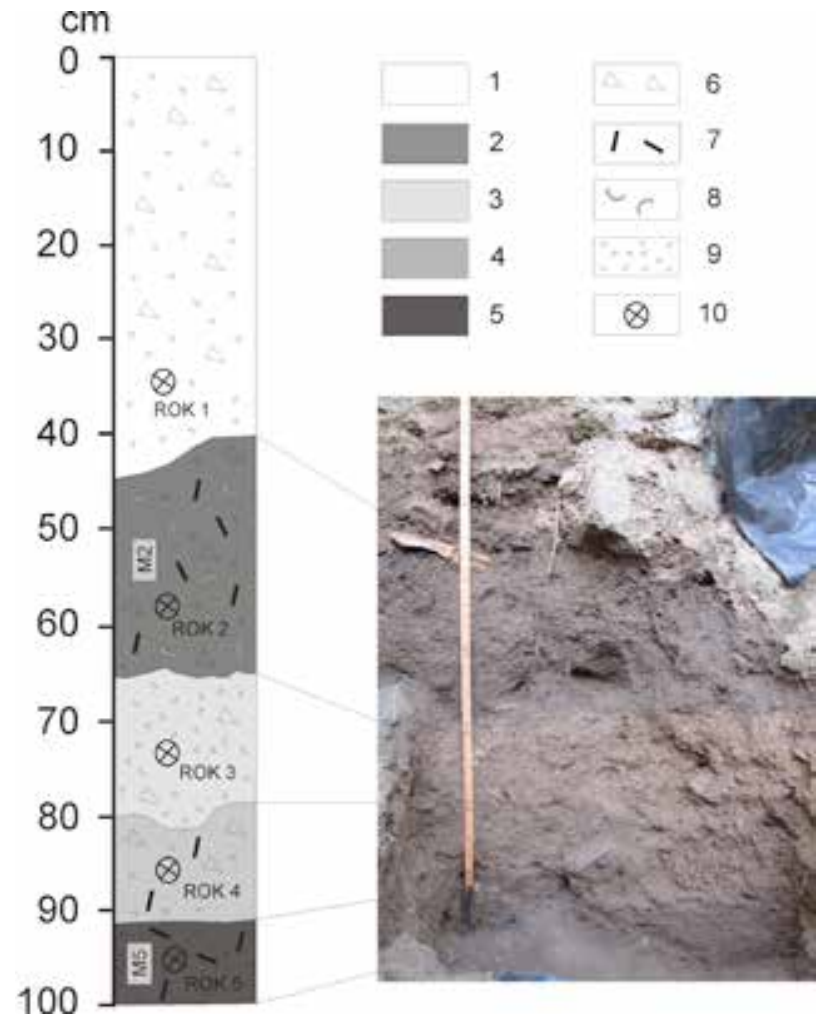

Obr. 10. Sedimentologický popis části profilu A-B. 1-5 - jednotlivé vyčleněné uloženiny; 6 - hrubé klasty; 7 - uhlíky; 8 keramika; 9 - detrit; 10 - místa odběrů vzorků na chemickou analýzu. Foto J. Mazáčková.

Abb. 10. Sedimentologische Beschreibung des Profilabschnitts A-B. 1-5 - einzelne ausgegliederte Ablagerungen; 6 - grobe Klasten; 7 -Holzkohle; 8-Keramik; 9-Detritus; 10 - Probeentnahmestellen für die chemische Analyse. Foto J. Mazáčková. 
Horizont 3 je tvořen archeologicky vyčleněnou vrstvou 6-8-012, metráž od povrchu je 160-185 cm (obr. 9, 10). Jde o nevytrríděný, pórovitý, písčitý sediment s detritem o velikosti $0,5-1 \mathrm{~cm}$ a jednotlivými klasty do velikosti $5 \mathrm{~cm}$. Zastoupení detritu je ca $40 \%$. Barva sedimentu je dána proměnlivou barvou stavební suti, jíž je tvořen, a kolísá zhruba v odstínech světle šedé $(10 \mathrm{YR} 8 / 1 ; 8 / 2 ; 7 / 1 ; 7 / 2)$.

Horizont 4 je tvořen archeologicky vyčleněnou vrstvou 6-8-011, metráž od povrchu je 160-185 cm (obr. 9, 10). Jde o nevytříděný, pórovitý sediment tmavě žlutohnědé barvy (dle Munsela průměrně $10 \mathrm{YR} 4 / 4$ ), velikost klastů je do $5 \mathrm{~cm}$, zastoupení klastů je ca $20 \%$. Občasný výskyt uhlíků (do 5 \%). Přechod do podloží je ostrý.

Horizont 5 je tvořen archeologicky vyčleněnou vrstvou 6-8-013, metráž od povrchu je 185-190 cm (obr. 9, 10). Jde o středně pórovitý, středně vytříděný sediment tmavě hnědé barvy (dle Munsela 10YR 3/3), analogický zhruba horizontu č. 2. Obsah uhlíků a mikrouhlíků ca do $20 \%$. Na bázi ukončeno velkými balvany, tj. vrstvou označenou jako 6-8-014.

Horizont 6 byl př́stupný až v sezóně 2012, a proto není zahrnut v úseku profilu A-B čtverce 6/8 (vrstva 6-8-025). Byl z něj odebrán vzorek M4. Jde o homogenní tmavě hnědý relativně vytrríděný prachovitopísčitý sediment (dle Munsela 10YR 2/2) s minimem klastů, avšak s přítomností uhlíků (obr. 7/2). Metráž od povrchu je 200-220 cm (obr. 6, 8:2).

\subsubsection{Mikromorfologický popis}

Mikromorfologický popis byl proveden u celkem čtyř vzorků odebraných uprostřed vrstvy 6-8-009 (vzorek M2) z rozhraní vrstev 6-8-015, 6-8-010 a 6-8-009 (vzorek M3), dále pak z vrstvy 6-8-013 (vzorek M5) a vrstvy 6-8-025 (vzorek M4; obr. 8:2; 9; 10). Mikromorfologický popis je uveden textovou formou, u vzorku M3 je popsána pouze jílovitá vrstva (subfacie A), protože charakteristika jejího nadloží a podloží je obdobná jako u vzorku M2. Interpretace jednotlivých vrstev na základě hlavních mikromorfologických znaků je zhodnocena v diskusi.

\section{Vzorek ROK M2}

Mikrostruktura tohoto vzorku je granulární až agregátová (obr. 11:A), místy subangulárně bloková. Podle $\mathrm{C} / \mathrm{F}$ rozložení je možné popsat tento sediment jako nevytříděný písčitoprachovitý materiál, v němž klasty o velikosti nad jeden milimetr tvoří minimálně $30 \%$ celkové masy. $\mathrm{U} \mathrm{C} / \mathrm{F}$ limitu, tedy poměru hrubozrnné $\mathrm{k}$ jemnozrnné frakci, $0,5 \mathrm{~mm}$ je tento poměr $40: 60$ a u jemnějšího poměru, tedy v rámci matrix $(\mathrm{C} / \mathrm{F} 0,1 \mathrm{~mm})$, je poměr mezi hrubozrnnou a jemnozrnnou hmotou $50: 50$. Póry obsažené ve studovaných vzorcích jsou téměř výlučně tzv. složitě shlukující, tedy póry oddělující agregáty a klasty od sebe. Distribuce klastů v matrix je porfyrická. Klasty samy jsou tvořeny orstrohrannými úlomky hornin o různé velikosti.

Tyto horniny jsou většinou nezvětralé. Samostatné minerály, které tvoří hrubozrnnou složku vzorku, jsou zastoupeny především biotitem (50 \%), křemenem (30 \%) a živci (20\%). Matrix je bohatá na jemnozrnné rozptýlené karbonáty a její barva je béžová až béžovošedá, dvojlom díky prrítomnosti rozptýlených karbonátů krystalický. Ve vzorku byly občasně identifikovány rozptýlené fytolity a jen velmi zrrídka krystaly oxalátů. Organická hmota je zastoupena především rozloženou tmavou opakní hmotou a uhlíky. Velmi zř́idka byla identifikována částečně rozložená organická hmota a v malé míře tzv. tečkování způsobené jemnozrnným humusem. Př́itomnost kostí byla velmi malá. Vzorek neobsahoval Fe nodule ani povlékání zrn karbonáty či jílovou matrix.

\section{Vzorek ROK M3 (subfacie A)}

Mikrostruktura tohoto vzorku je subangulárně bloková, prasklinová a podle $\mathrm{C} / \mathrm{F}$ rozložení je možné popsat tento sediment jako relativně vytříděný prachovitojílovitý materiál s místy usměrněnou matrix (obr. 11:B), v níž klasty o velikosti nad jeden milimetr tvoří maximálně 3 \% celkové masy. Směrem do nadloží je zřetelná vyšší fragmentarizace a promíchávání vrstvy s nadložním materiálem, přičemž se objevují i uhlíky a mikrouhlíky ve výraznějším množství. $\mathrm{U}$ C/F limitu, tedy poměru hrubozrnné $\mathrm{k}$ jemnozrnné frakci, $0,5 \mathrm{~mm}$ je tento poměr $5: 95$ 
a u jemnějšího poměru, tedy $\mathrm{v}$ rámci matrix $(\mathrm{C} / \mathrm{F} 0,1 \mathrm{~mm})$, je poměr mezi hrubozrnnou a jemnozrnnou hmotou $20: 80$. Póry obsažené ve studovaných vzorcích jsou představovány trhlinami, které tvoří subangulárně blokovou sít'. Distribuce klastů v matrix je porfyrická. Klasty samy jsou tvořeny poloostrohrannými klasty křemene a živce a podlouhlými krystaly slídy.

Matrix je šedá, bohatá na akumulace jílových minerálů, které jsou místy horizontálně usměrněné (obr. 11:B). Dvojlom je striatický, místy tečkovaný. Akumulace jílu netvoří náteky, jde povětšinou o usměrněné akumulace nebo samostatné redeponované starší jílové náteky nebo výplně. Př́ítomnost fytolitů nebo krystalů oxalátů nebyla potvrzena. Organická hmota je zastoupena především rozloženou hnědou (do 10 \%) a černohnědou (do 5 \%) opakní hmotou a mikrouhlíky. Úlomky kostí nebyly identifikovány, stejně jako Fe nodule nebo povlékání zrn karbonáty.

\section{Vzorek ROK M5}

Tento vzorek je velmi podobný vzorku ROK M2. Mikrostruktura tohoto vzorku je granulární až agregátová, místy subangulárně bloková. Ve svrchní části vzorků jsou v rámci jednotlivých bioturbovaných agregátů viditelné náznaky horizontálního usměrnění. Podle $\mathrm{C} / \mathrm{F}$ nevytříděný písčitoprachovitý materiál, v němž klasty o velikosti nad jeden milimetr tvoří minimálně $30 \%$ celkové masy. U C/F limitu, tedy poměru hrubozrnné $\mathrm{k}$ jemnozrnné frakci, $0,5 \mathrm{~mm}$ je tento poměr $40: 60$ a u jemnějšího poměru, tedy v rámci matrix $(\mathrm{C} / \mathrm{F} 0,1 \mathrm{~mm})$, je poměr mezi hrubozrnnou a jemnozrnnou hmotou $50: 50$. Póry obsažené ve studovaných vzorcích jsou téměř výlučně tzv. složitě shlukující, tedy póry oddělující agregáty a klasty od sebe. Jen výjimečně jsou př́tomny póry typu kanálků. Distribuce klastů v matrix je porfyrická. Klasty samy jsou tvořeny orstrohrannými úlomky hornin o různé velikosti. Protože je velikost přítomných klastů proměnlivá, vzorek působí nevytrríděně, přičemž úlomky hornin dosahují velikosti nad $1 \mathrm{~cm}$.

Tyto horniny jsou většinou nezvětralé. Samostatné minerály, které tvoří hrubozrnnou složku vzorku, jsou zastoupeny především biotitem (50 \%), křemenem (30 \%) a živci (20 \%). Matrix je bohatá na jemnozrnné rozptýlené karbonáty a její barva je světlehnědá, dvojlom díky přítomnosti rozptýlených karbonátů krystalický. Ve vzorku byly občasně identifikovány rozptýlené fytolity a jen velmi zrrídka krystaly oxalátů. Organická hmota je zastoupena především rozloženou tmavou opakní hmotou a uhlíky. Velmi zrrídka byla identifikována částečně rozložená organická hmota a v malé míře tzv. tečkování způsobené jemnozrnným humusem. Přítomnost kostí byla velmi malá, a to ve formě spálené a nespálené. Byl zde zachycen fragment rybí kosti (obr. 11:D). Vzorek neobsahoval Fe nodule ani povlékání zrn karbonáty či jílovou matrix.

\section{Vzorek ROK M4}

Je zřejmá materiálová a strukturní analogie mezi vzorky 2, 5 a 4. Přesto jsou u vzorku M4 rozeznatelné menší odlišnosti. Mikrostruktura tohoto vzorku je mikroagregátová mezi klasty, místy jsou zde však znatelné horizontální pukliny (obr. 11:C) a náznaky subangulárně blokové mikrostruktury. Místy se objevují i dutiny. Podle $\mathrm{C} / \mathrm{F}$ jde o nevytř́iěný písčitoprachovitý materiál, v němž klasty o velikosti nad jeden milimetr tvoří ca $20 \%$ celkové masy. U C/F limitu, tedy poměru hrubozrnné $\mathrm{k}$ jemnozrnné frakci, $0,5 \mathrm{~mm}$ je tento poměr $25: 75$ a u jemnějšího poměru, tedy v rámci matrix (C/F 0,1 mm), je poměr mezi hrubozrnnou a jemnozrnnou hmotou $40: 60$. Distribuce klastů v matrix je porfyrická. Klasty samy jsou tvořeny ostrohrannými úlomky hornin o různé velikosti.

Tyto horniny jsou částečně zvětralé. Samostatné minerály, které tvoří hrubozrnnou složku vzorku, jsou zastoupeny především rozvětraným biotitem (30 \%), křemenem (40 \%) a živci (30 \%). Matrix je bohatá na jemnozrnné rozptýlené karbonáty a její barva je světlehnědá, dvojlom díky př́ítomnosti rozptýlených karbonátů krystalický, místy tečkovaný v důsledku přítomnosti akumulací jílových minerálů. Ve vzorku byly občasně identifikovány rozptýlené fytolity. Organická hmota je zastoupena především rozloženou hnědou opakní hmotou a uhlíky včetně mikrouhlíků. Místy byla identifikována částečně rozložená organická hmota, především ve formě semen se znatelnou vnitřní strukturou. Přítomnost kostí byla velmi malá, a to ve formě spálené a nespálené. Vzorek neobsahoval Fe nodule. 

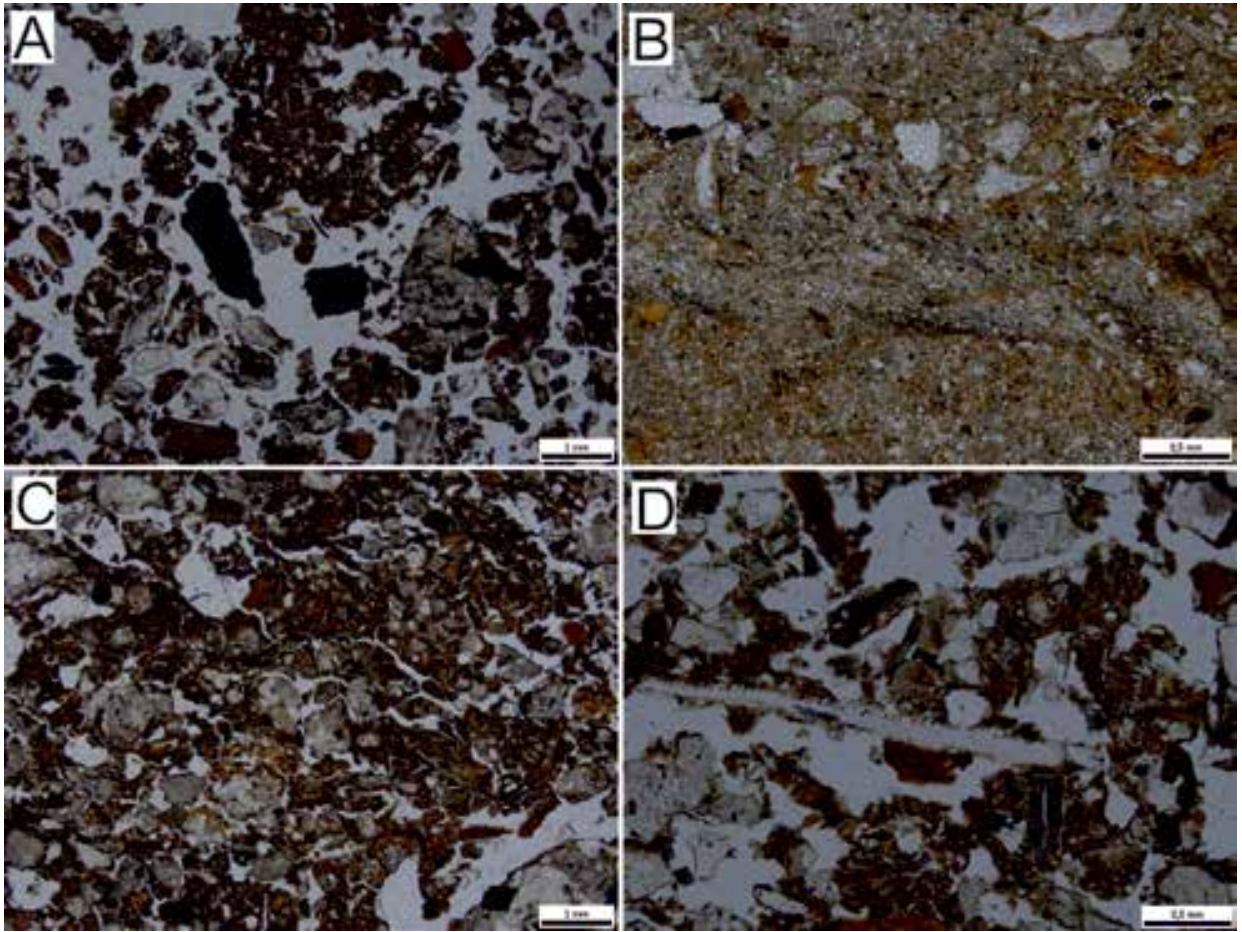

Obr. 11. Mikromorfologická dokumentace vybraných struktur jednotlivých vrstev. A - granulární mikrostruktura u vzorku M2; B - horizontální uložení jemnozrnné matrix u vzorku M3, resp. proplástku 6-8-010; C - horizontální póry indikující tlak z nadloží odpovídající pocházení u vzorku M4 z báze profilu; D-fragment rybí kosti zachycený ve vzorku M5, tj. vrstva 6-8-013. Foto L. Lisá.

Abb. 11. Mikromorphologische Dokumentation ausgewählter Strukturen der einzelnen Schichten. A - granulare Mikrostruktur bei Probe M2; B - horizontale Ablagerung feinkörniger Matrix bei Probe M3, bzw. bei Zwischenschicht 6-8-010; C - die horizontalen Poren indizieren Druck vom Überhängenden, der bei Probe M4 als von der Basis des Profils stammend entspricht; D - in Probe M5, d.h in Schicht 6-8-013 erfasstes Fischgrätenfragment. Foto L. Lisá.

\subsubsection{Chemická charakteristika studovaných horizontı̊}

V rámci studovaných horizontů odkrytých před sezónou 2012 byly měřeny obsahy $\mathrm{Al}, \mathrm{Ca}, \mathrm{Fe}$, $\mathrm{K}, \mathrm{Mg}, \mathrm{Mn}, \mathrm{Na}, \mathrm{P}, \mathrm{S}$ a hmotnostní magnetická susceptibilita (tab. 2). Největší výpovědní hodnotu přinášejí obsahy fosforu, železa a vápníku. Zatímco celkový obsah fosforu a případně železa indikuje antropogenní znečištění formou organického odpadu (nárůst u horizontu 2), obsahy vápníku indikují zvýšenou př́itomnost odpadního stavebního materiálu (vrstvy 1, 2 a 4). Hodnoty magnetické susceptibility jsou nejvyšší v horizontu 3, makroskopicky interpretovaném jako horizont tvořený odpadní sutí. Navýšení magnetické susceptibility lze nejspíše přičítat přítomnosti propálené mazanice.

\begin{tabular}{|c|c|c|c|c|c|c|c|c|c|c|}
\hline & \multicolumn{9}{|c|}{ mg prvku vyloužené z 1 g vzorku } & \multirow{2}{*}{$\begin{array}{c}\text { hmotnostní MS } \\
{\left[10^{-9 *} \mathrm{~m}^{3} \cdot \mathrm{kg}^{-1}\right]}\end{array}$} \\
\hline & $\mathrm{Al}$ & $\mathrm{Ca}$ & $\mathrm{Fe}$ & $\mathrm{K}$ & $\mathrm{Mg}$ & $\mathrm{Mn}$ & $\mathrm{Na}$ & $P$ & S & \\
\hline ROK 1 & 2,8 & 10,8 & 4,7 & 3,7 & 3,5 & 0,3 & 0,1 & 1,0 & $<$ & 181,6 \\
\hline ROK 2 & 5,2 & 14,8 & 9,6 & 7,5 & 5,5 & 0,5 & 0,1 & 2,1 & $<$ & 236,6 \\
\hline ROK 3 & 3,8 & 7,2 & 7,7 & 6,4 & 3,1 & 0,1 & 0,1 & 0,7 & 0,1 & 316,1 \\
\hline ROK 4 & 2,6 & 11,3 & 4,4 & 4,2 & 2,5 & 0,1 & 0,1 & 0,7 & 0,1 & 250,9 \\
\hline ROK 5 & 2,4 & 5,2 & 4,8 & 4,7 & 2,0 & 0,1 & 0,1 & 0,8 & 0,2 & 276,7 \\
\hline
\end{tabular}

Tab. 2. Chemická analýza základních prvků ze studovaných horizontů a hodnoty hmotnostní magnetické susceptibility. Tab. 2. Chemische Analyse der Grundelemente aus den untersuchten Horizonten und Massewerte der magnetischen Suszeptibilität. 


\section{Diskuse}

Studovaný profil představuje výplň do skály vytesaného objektu s původní funkcí hradního prríkopu. Lze tedy předpokládat, že po zániku původní funkce př́íkopu byla vzniklá deprese cíleně zaházena odpadním materiálem. Při agradaci výplně této struktury vzniklo postupně několik horizontů, které bylo možné odlišit jak na základě změny litologie, tak na základě změny barvy. $\mathrm{Z}$ artefaktů makroskopicky identifikovatelných ve výplni lze soudit, že minimálně horizonty 6-8-004 a 6-8-012 jsou tvořeny odpadní sutí pocházející z některých stavebních či demoličních fází hradu. Vzhledem k průměrným hodnotám magnetické susceptibility, i když mírně zvýšeným lze soudit, že materiál výplně nebyl teplotně př́lliš ovlivněn, a nedošlo tak k druhotnému vzniku magnetických minerálů. Poměrně nízké obsahy fosforu a síry svědčí o nepřítomnosti exkrementů (Goldberg-Macphail 2006). Naopak poměrně vysoké obsahy karbonátů jsou zřejmé u všech studovaných vrstev. Souvisí to pravděpodobně s depozicí stavebního materiálu. Zvýšené hodnoty ve vrstvě 2 souvisí zř́ejmě s př́tomností stavebního odpadu, jako jsou fragmenty malty. Ty byly identifikovány i mikromorfologicky.

Horizontálně uložené tmavé vrstvy byly předmětem detailnějšího studia (vzorky z vrstev 6-8-0010; 6-8-009, 6-8-013 a 6-8-025). Jejich primární interpretace se vzhledem k horizontálnímu uložení nabízela jako možný komunikační prostor. Tyto horizonty mají výrazně tmavší barvu, která evokuje prŕípadnou přítomnost organického odpadu, a tedy i fáze spojené s možným stabilnějším dlouhodobým využíváním studovaného úseku a pomalejší agradací jemnozrnného materiálu. Hodnoty naměřené chemickým rozkladem (tab. 2) nijak nevybočují ve srovnání s ostatními horizonty. Póry, které ve studovaných vzorcích převládají, resp. dominují, indikují fakt, že materiál nebyl do výplně naplaven (splachy, deště), ale byl tam postupně agradován a bioturbací formován do současné podoby. Jde o odpadní materiál, čemuž nasvědčuje množství mikrouhlíků rozložené organické hmoty, zbytků kostí a také stavebního materiálu. Granulární mikrostruktura zachycená ve všech studovaných vzorcích svědčí o vysoké biologické aktivitě (Stolt-Lintbo 2010). Minimální přítomnost jílovitých nebo prachovitých náteků je však dokladem absence dlouhodobějšího půdního vývoje a vzniku iluviálních horizontů. Dané horizonty tedy korespondují nejlépe s půdním A horizontem. Vzorek odebraný z báze z vrstvy označené jako 6-8-025 má mírně odlišné mikrostrukturní znaky a litologickou náplň. Dominují mikrouhlíky, zbytky nerozložené organické hmoty a náznaky horizontálního uložení. Daná vrstva může být proto interpretována jako pravděpodobně pochozí horizont. V tomto prŕípadě se tudíž původní interpretace potvrzuje, i když nejde o podlahový horizont, ale spíše intenzivněji využívaný venkovní prostor, který nebyl zpevněn hrubšími klasty.

V hrubozrnné frakci v př́padě všech studovaných vzorků dominují především biotity, křemeny a živce, což indikuje typ grafitické horniny či pararuly. Vzhledem k provenienci tohoto typu hornin (obr. 2:2) každopádně jde o horniny s velice blízkou proveniencí. Fakt, že jednotlivé klasty jsou ostrohranné, svědčí o tom, že nepochází z fluviálního transportu, respektive nebyly na toto místo deponovány sedimenty z blízké nivy. Toto ovšem neplatí u vzorku M3, resp. $\mathrm{z}$ proplástku, který je $\mathrm{v}$ tomto vzorku zachycen. Zde jde o cíleně vytvořenou vrstvu, čemuž nasvědčuje usměrnění klastů ve vnitřní struktuře vzorku. Může jít o zpevnění konstrukce terasy II. Povrch tohoto proplástku nese evidentně známky užívání, je mechanicky poškozen a objevuje se zde akumulace uhlíků. Mluvíme v tomto případě tedy opět o pochozím horizontu, nicméně nebyl zachycen $\mathrm{v}$ celé šiŕi př́íkopu.

Otázkou zůstává, zda jde u studovaných horizontů o depozice organického odpadu obsahující např́íklad exkrementy či nerozloženou organickou hmotu. Fytolity jsou ve studovaných vzorcích obsaženy, avšak v poměrně malé míře rozhodně neodpovídající akumulaci exkrementů (Goldberg-Macphail 2006). Dalším z možných indikátorů př́itomnosti exkrementů, či organického odpadu, by u tak alkalického materiálu, jako je studovaná výplň, byly krystaly štavelanů (Canti 1998; 1999; Brochier 1996). Ty jsou však prŕítomny jen ve velmi omezené míre a rozhodně nemohou být interpretovány jako akumulace $\mathrm{v}$ důsledku depozice organického materiálu. Lze tedy říci s určitostí, že studovaný materiál neobsahuje exkrementy býložravců. Vzhledem k ne- 
prrítomnosti fosfatických akumulací či natrávených kostí lze říci, že studovaný materiál neobsahuje ani exkrementy masožravců. Přítomnost kostí je velmi malá, přestože byly identifikovány i makroskopicky. Svědčí to opět o tom, že kosti byly do prostoru př́íkopu deponovány jako kuchyňský odpad.

Matrix studovaných vzorků M2 a M5 nevykazuje žádné známky usměrnění ani kompakce. Lze tedy vyloučit, že by koridor sloužil v době agradace těchto horizontů jako pochozí oblast. To však neplatí, jak již bylo zmíněno, v př́ípadě povrchu proplástky označené archeologicky jako 6-8-010 a také v př́padě 6-8-025. Vzhledem k neprrítomnosti Fe nodulí (Lindbo et al. 2011) a koncentrací karbonátů v důsledcích iluviace (Durand et al. 2011) lze vyloučit fakt, že by v př́kopu někdy stagnovala voda. S největší pravděpodobností tedy opravdu jde pouze o místo pro akumulaci druhotného odpadu, a to jak organického, tak stavebního, a nikoliv např́íklad o sanační vrstvu ochraňující proti vzlínající vodě. Přetržky v akumulaci musely být relativně krátké, protože nedošlo k vytvoření typických pedogenních prvků, avšak dostatečně dlouhé, aby lokalita zarostla vegetací a došlo $\mathrm{k}$ destrukci organických zbytků a k částečnému smazání vrstevnatosti vytvořené pochozí činností.

\section{Závěry}

Ze získaných dat lze vyvodit následující závěry. Studovaný profil je situován v prostoru sníženiny, interpretované archeologicky jako př́kop. Výplň sníženiny je tvořena antropogenně deponovaným materiálem a na základě litologických a barevných změn byly exkavovány uloženiny. O tmavších vrstvách s náplní odpadu (především keramika, kosti) se uvažovalo jako o odpadních s využitím jako komunikačního prostoru. Komunikační funkce se hlavně vyvozovala ze závěrů stavební podoby hradu a využívání předhradí zahrnujícího i příkop pro volný pohyb, a to především zvířectva. Světlejší uloženiny představují stavební odpad nebo destrukční sutě a jsou použity jako vyrovnávky pro další antropogenní aktivity. Tyto horizonty po stránce chemického složení vykazují minimální rozdíly. Jde vždy o velmi špatně vytříděný materiál tvořený odpadní sutí a písčitoprachovitou matrix. Odpadní sut' je z hlediska horninového tvořena horninami místní provenience. Na části klastů zůstala zachována tmelicí stavební hmota. Klasty jsou ostrohranné, což svědčí o nepřítomnosti fluviálních sedimentů. Matrix je silně vápnitá, obsahuje mikrouhlíky.

Vrstvy vybrané pro mikromorfologickou analýzu z důvodu možné přítomnosti organického odpadu či pochozích vrstev vykazují navzájem poměrně malé rozdíly. Výjimkou je vzorek odebraný na bázi, tj. ve vrstvě 6-8-025, a charakteristika proplástku označeného 6-8-010. V těchto dvou př́ípadech byla doložena i komunikační funkce místa. Hodnoty magnetické susceptibility neindikují př́ítomnost výrazně magnetických minerálů vzniklých v důsledku teplotních změn, nejde o materiál z destrukcí shořelých částí hradu. Nízké hodnoty fosforu a síry indikují poměrně nízké zastoupení organické hmoty.

Na základě nepřítomnosti fytolitových akumulací a nepř́itomnosti oxalátů byla vyloučena přítomnost exkrementů býložravců. Nepřítomnost fosfatických akumulací a natrávených kostí vylučuje přítomnost exkrementů masožravců. Velmi nízká přítomnost jednotlivých krystalů oxalátů indikuje minimální přítomnost organického odpadu typu exkrementů, a proto lze prostor definovat jako odpadní areál s běžným provozním odpadem hradu.

Vzhledem k tomu, že mikrostruktura vzorků 6-8-009 a 6-8-013 je granulární a není viditelné žádné přednostní usměrnění, lze říci, že materiál těchto dvou vrstev byl agradován antropogenně, tedy naházením, a že po něm nebylo pravidelně popocházeno. Vzhledem k nepř́tomnosti Fe nodulí lze vyloučit stagnující vodu na bázi př́ikopu. Náznaky horizontálního usměrnění matrix na bázi profilu ukazují na jiný typ formačních procesů a na přítomnost komunikačního prostoru.

Příkop po vyplnění vyrovnávací vrstvou 6-8-033 sloužil jako místo deponování běžného provozního odpadu (kosti, keramika), ve fázi před rokem 1306/1307 zároveň i jako komunikační koridor. Uloženina 6-8-013, která se zformovala po přestavbě hradu roku 1306/1307, byla odpad- 
ní vrstvou bez pochozí funkce a místo sloužilo jako skládka běžného provozního a kuchyňského odpadu. Při přestavbě hradu dokumentované planýrkou 6-8-012 byl na její povrch naházen opět kuchyňský odpad (6-8-009). Pak se stavebník rozhodl změnit tuto část hradu a vytvořil terasu II., se kterou souvisí uhutnění jejího povrchu vrstvou 6-8-010. Zánik nebo další odpad dokumentuje vrstva 6-8-15, kterou následně převrstvuje stavební aktivita v př́ikopu a vybudování terasy I. a její používání dokumentované vrstvou 6-8-008. Bývalý příkop se uzavřel maltovou vrstvou 6-8-017 a 6-8-027 položenou na stavební vyrovnávce.

Př́íkop s odpadem a pochozí funkcí na počátku 14. století ještě plnil svou funkci velmi omezeně. Záměrné odhazování odpadu snížilo defenzivní funkci fortifikačního prvku. Funkce předhradí v nejstarších fázích hradu s vývojem do poloviny 14 . století je doložena v tomto místě jako prostor související s běžným provozem kuchyně a deponováním jejího odpadu.

Tato studie je výstupem projektu "Historické využívání krajiny Českomoravské vrchoviny v pravěku a středověku" Programu aplikovaného výzkumu a vývoje národní kulturní identity NAKI DF13P010VV005.

\section{Prameny}

COUFAL, B., 1958: Terénní deník z archeologického výzkumu hradu Rokštejn. Digitalizovaný rukopis, Ústav archeologie a muzeologie FF MU. Brno.

CDM VI: Codex diplomaticus et epistlorais Moraviae VI (Chytil, J., ed.). Brünn 1854.

CDM VII: Codex diplomaticus et epistlorais Moraviae VII (Chytil, J., ed.). Brünn 1858.

CDM XI: Codex diplomaticus et epistlorais Moraviae XI (Brandl, V., ed.). Brünn 1885.

Die Landtafel des Markgrathums Mähren. Brünner Cuda (Chlumecký, P.-Chytil, J.-Demuth, C.-Wolfskron, A. R., edd.). Brünn 1856.

\section{Literatura}

BAJER, A. a kol., 2013: Bajer, A.-Dejmal, M.-Lisá, L.-Kočár, P.-Kočárová, R.-Nývltová Fišáková, M.Petr, L., Středověká stáj ve světle moderních environmentálních metod, Živá archeologie - REA 15, $39-44$.

BROCHIER, J. E., 1996: Leaves or mature? Observations on the role of spherulitic particles in the interpretation of Holocene archaeological deposits, Anthropozoologica 24, 19-30.

BULLOCK, P.-MURPHY, C. P., 1983: Soil micromorphology. Berkhamsted.

CANTI, M. G., 1998: The micromorphological identification of faecal spherulites from Archaeological and Modern materials, Journal of Archaeological Science 25, 435-444. DOI 10.1006/jasc.1997.0210

- 1999: The production and preservation of faecal spherulites: animals, environment and taphonomy, Journal of Archaeological Science 26, 251-258. DOI 10.1006/jasc.1998.0322

ČAPEK, L., 2013: Archeologické transformace v městském prostředí. I. Textová část. Rukopis disertační práce, KAR FF ZČU v Plzni.

DURAND, N.-MONGER, H. C.-CANTI, M. G., 2011: Calcium Carbonate Features. In: Stoops, G.-Marcelino, V.-Mees, F., Interpretation of micromorphological features of soils and regoliths. Amsterdam.

DURDÍK, T., 2010: Několik poznámek k české hradní každodennosti - Einige Anmerkungen zum bohmischen Burgalltag, AH 35, 45-61.

GOLDBERG, P.-MACPHAIL, R., 2006: Practical and theoretical geoarchaeology. Malden-Oxford-Victoria.

KEMP, R. A., 2007: Soil Micromorphology. In: Encyclopedia of Quaternary Science 3 (Ellias, S. A., ed.), 2103-2114. London. DOI 10.1016/B0-444-52747-8/00153-8

LINDBO, D.-STOLT, M. H.-VEPRASKAS, M. J., 2011: Redoximorphic Features. In: Stoops, G.-Marcelino, V.-Mees, F., Interpretation of micromorphological features of soils and regoliths. Amsterdam.

LISÁ, L. a kol., 2015: Lisá, L.-Komoróczy, B.-Vlach, M.-Válek, D.-Bajer, A.-Kovárník, J.-Rajtár, J.Hüssen, C. M.-Šumberová, R., How were the ditches filled? Sedimentological and micromorphological classification of formation processes within graben-like archaeological objects, Quaternary International $370,66-76$.

MAZÁČKOVÁ, J., 2011: Obléhací postavení u hradu Rokštejna - Belagerungsstellungen bei der Burg Rokštejn, AH 36, 61-85. 
- 2013: Militária z hradu Rokštejna v širším středoevropském kontextu. Rukopis disertační práce, ÚAM FF MU, Brno.

- 2013a: Rokštejn Castle (Czech Republic): archaeological evidence of military activities. In: Lech, M., Weapons Bring Peace? Warfare in Medieval and Early Modern Europe, 255-289. Wrocław.

MAZÁČKOVÁ, J.-MĚŘíNSKÝ, Z., 2011: Archeologický výzkum hradu Rokštejna v letech 2007-2009 (sezóna 26.-28.), AVV 2, 18-22.

MĚŘÍNSKÝ, Z., 2007: Hrad Rokštejn. Dějiny, stavební vývoj a výsledky čtvrtstoletí archeologického výzkumu 1981-2006. Brtnice - Brno.

NEUSTUPNÝ, E., 2007: Metoda archeologie. Plzeň.

SEDLÁČEK, A., 2003: Atlasy erbů a pečetí české a moravské středověké šlechty. Svazek 5. Atlas pečetí. Soupisy, rejstř́ík, faksimile. Praha.

SCHIFFER, M. B., 1972: Archaeological context and systemic context, American Antiquity 37, 156-165. DOI $10.2307 / 278203$

- 1983: Toward the identification of formation processes, American Antiquity 48, 675-706. DOI 10.2307/279771

- 1987: Formation Processes of the archaeological Record. Albuquerque.

STOOPS, G., ed., 2003: Guidelines for Analysis on Description of Soil and Regolith Thin Sections. Soil Science Society of America, Inc., 1-141. Madison.

STOLT, M. D.-LINTBO, D. L., 2010: Soil organic matter. In: Stoops, G.-Marcelino, V.-Mees, F., Interpretation of micromorphological features of soils and regoliths, 369-396. Amsterdam.

ŠABATOVÁ, L.-SOUKUP, M. B.-KYNCL, T., 2010: Nové poznatky z průzkumů hradu Rokštejn - Neue Erkenntnisse aus den Untersuchungen der Burg Rokštejn. In: Dějiny staveb 2009. Sborník příspěvků z konference Dějiny staveb, 193-209. Plzeň.

VOHRYZEK, S., 2011: Hrut z Rokštejna, moravský podkomoří? - Hrut from Rokštejn, Moravian vicechamberlain?, AVV 2, 46-50.

- 2012: Stř́žovci v 2. polovině 14. století - The House of Střížov in the 2nd half of the 14th century, AVV 3 , 67-74.

- 2013: K počátkům působení pánů z Valdštejna na jihozápadní Moravě - The Beginning of the Rule of the Lords of Wallenstein, AVV 4, 84-90.

\section{Zusammenfassung}

\section{Geoarchäologische Studie zu Entstehung, Nutzung und Untergang des Burggrabens auf Burg Rokštejn}

Die auf Burg Rokštejn an dem im Planum 6/8 (Abb. 1, 3, 4) befindlichen Graben (Obj. 84) durchgeführte archäologische Grabung wurde um eine geoarchäologische Untersuchung der Schichten ergänzt, die einen begehbaren Charakter oder einen Abfallcharakter für eine mikromorphologische Analyse aufwiesen. Die Verfüllung der absichtlich in den Felsen gehauenen Bodensenkung besteht aus anthropogen deponiertem Material, und den lithologischen und farblichen Veränderungen nach zu urteilen, wurden Ablagerungen auch exkaviert. Die dunkleren Schichten mit einer Abfallverfüllung (vor allem Keramik, Knochen) wurden als Abfallschichten angesehen, die auch als Verkehrswegeraum benutzt wurden. Die Verkehrswegefunktion wurde hauptsächlich aus den Schlussfolgerungen bzgl. der baulichen Form der Burg und durch die auch den sich füllenden Graben umfassende Nutzung der Vorburg abgeleitet, sich frei darauf bewegen zu können, und zwar vor allem Tiere betreffend. Hellere Ablagerungen stellen Bauschutt oder Zerstörungsschutt dar und werden als Nivellierschichten für weitere anthropogene Aktivitäten verwendet. Diese Horizonte weisen seitens der chemischen Zusammensetzung nur minimale Unterschiede auf. Es handelt sich um sehr schlecht sortiertes Material, das aus Abfallschutt und einer sandsteinstaubigen Matrix besteht. Hinsichtlich des Gesteins setzt sich der Abfallschutt aus Gesteinen lokaler Provenienz zusammen. An Teilen der Klasten ist ein kittartiger Baustoff erhalten geblieben. Die Klasten sind scharfkantig, was auf die Abwesenheit von fluvialen Sedimenten hindeutet. Die Matrix ist stark kalkig und enthält Mikroholzkohle.

Die für eine mikromorphologische Analyse ausgewählten Schichten - Probe ROK M2 (6-8-009), ROK M3 (6-8-015, 6-8-010, 6-8-009), Probe ROK M4 (6-8-025) und Probe ROK 
M5 (6-8-013) - weisen wegen eines möglichen Vorhandenseins von organischem Abfall oder begehbaren Schichten untereinander nur relativ geringe Unterschiede auf (Abb. 7, 8, 9). Eine Ausnahme bildet die in der Basis, d.h. die in Schicht 6-8-025 genommene Probe und die Charakteristika der als 6-8-010 bezeichneten Zwischenschicht. In diesen beiden Fällen wurde auch eine Verkehrswegefunktion des Korridors nachgewiesen. Die Werte der magnetischen Suszeptibilität indizieren kein Vorhandensein von durch Temperaturänderungen entstandenen, deutlich magnetischen Mineralien, es handelt sich um kein Material, das aus den Zerstörungsschichten des verbrannten Teils der Burg stammt. Die geringen Phosphor- und Schwefelwerte indizieren ein relativ geringes Vorkommen organischer Stoffe.

Aufgrund des Fehlens von phytolithischen Anhäufungen und des Fehlens von Oxalaten wurde das Vorhandensein von Exkrementen von Pflanzenfressern ausgeschlossen. Das Fehlen von phosphatischen Anhäufungen und teilweise verdauten Knochen schließt auch das Vorhandensein von Exkrementen von Fleischfressern aus. Ein sehr geringes Vorhandensein der einzelnen Kristalle der Oxalate indiziert ein minimales Vorhandensein von organischem Abfall vom Typ Exkremente, weswegen der Raum als mit einer funktonierenden Küche verbundenes Abfallareal definiert werden kann.

Hinsichtlich dessen, dass die Mikrostruktur der Proben 6-8-009 und 6-8-013 granular ist und keine Ausrichtungspräferenzen erkennbar sind, kann man sagen, dass das Material dieser beiden Schichten anthropogen aggradiert wurde, dass heißt durch Aufhäufen und dass sie danach nicht regelmäßig betreten wurden. Im Hinblick auf das Fehlen von Fe-Noduli kann stagnierendes Wasser auf der Basis des Grabens ausgeschlossen werden. Andeutungen einer horizontalen Ausrichtung der Matrix an der Basis des Profils weisen auf einen anderen Typ von Formationsprozessen und auf das Vorhandensein eines Verkehrswegs hin.

Der Graben diente nach der Verfüllung der Nivellierschicht 6-8-033 als Ort zur Ablagerung von Küchenabfällen, in der Phase vor dem Jahr 1306/1307 gleichzeitig auch als Verkehrswegkorridor. Ablagerung 6-8-013, die nach dem Umbau der Burg von 1306/1307 gebildet wurde, war eine Abfallschicht ohne begehbare Funktion, der Ort diente auch als Deponie für Küchenabfälle. Auf der Oberfläche der beim Umbau der Burg dokumentierten Aufschüttung 6-8-012 wurde abermals Küchenabfall aufgehäuft (6-8-009). Dann hat sich der Bauherr dazu entschlossen, diesen Teil der Burg zu ändern und schuf die Terrasse II., mit welcher die Verdichtung ihrer Oberfläche durch Schicht 6-8-010 zusammenhängt. Ein Untergang oder weiterer Abfall wird durch Schicht 6-8-15 dokumentiert, welche anschließend durch die Bauaktivitäten im Graben und durch den Bau von Terrasse I. und deren durch Schicht 6-8-008 dokumentierten Nutzung umgeschichtet wird. Die oberste Schicht des ehemaligen Grabens bestand aus den Mörtelschichten 6-8-017 und 6-8-027, mit denen die nivellierende Bauschicht bedeckt wurde.

Der Graben mit Abfall- und Begehfunktion erfüllte noch zu Beginn des 14. Jahrhunderts in sehr begrenztem Umfang seine Funktion. Die absichtliche Entsorgung von Abfall minderte die Funktion als Befestigungselement. Die Funktion der Vorburg ist in den ältesten Burgphasen mit einer bis Mitte des 14. Jahrhunderts andauernden Entwicklung an dieser Stelle als Raum mit üblichem Küchenbetrieb belegt, an dem auch Abfall deponiert wurde.

Mgr. Lenka Lisá, Ph.D., Ústav geologických věd Př́rodovědecké fakulty Masarykovy univerzity, Kotlářská 267/2, 61137 Brno, Česká republika, lisa@gli.cas.cz

Mgr. Jana Mazáčková, Ústav archeologie a muzeologie Filozofické fakulty Masarykovy univerzity, Joštova 13, 60200 Brno, Česká republika,jkrejsov@phil.muni.cz 
